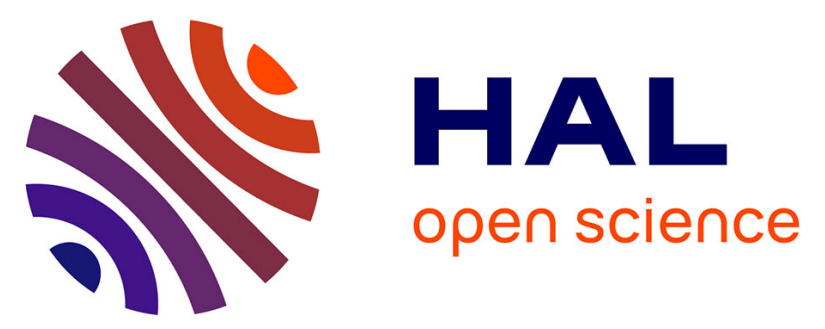

\title{
Neoproterozoic to Early Triassic tectono-stratigraphic evolution of Indochina and adjacent areas: A review with new data
}

\author{
Tri Van Tran, Michel Faure, Vuong Van V Nguyen, Hoang Huy H Bui,
} Michael Bryld Wessel B W Fyhn, Tuan Quang Q Nguyen, Claude Lepvrier, Tonny B Thomsen, Kenichiro Tani, Punya Charusiri

\section{To cite this version:}

Tri Van Tran, Michel Faure, Vuong Van V Nguyen, Hoang Huy H Bui, Michael Bryld Wessel B W Fyhn, et al.. Neoproterozoic to Early Triassic tectono-stratigraphic evolution of Indochina and adjacent areas: A review with new data. Journal of Asian Earth Sciences, 2020, 191, pp.104231. 10.1016/j.jseaes.2020.104231 . insu-02434825

\section{HAL Id: insu-02434825 \\ https://hal-insu.archives-ouvertes.fr/insu-02434825}

Submitted on 10 Jan 2020

HAL is a multi-disciplinary open access archive for the deposit and dissemination of scientific research documents, whether they are published or not. The documents may come from teaching and research institutions in France or abroad, or from public or private research centers.
L'archive ouverte pluridisciplinaire HAL, est destinée au dépôt et à la diffusion de documents scientifiques de niveau recherche, publiés ou non, émanant des établissements d'enseignement et de recherche français ou étrangers, des laboratoires publics ou privés. 


\section{Journal Pre-proofs}

Neoproterozoic to Early Triassic tectono-stratigraphic evolution of Indochina and adjacent areas: A review with new data

Tri Van Tran, Michel Faure, Vuong Van Nguyen, Hoang Huy Bui, Michael Bryld Wessel Fyhn, Tuan Quang Nguyen, Claude Lepvrier, Tonny B.

Thomsen, Kenichiro Tani, Punya Charusiri

PII:

S1367-9120(20)30006-7

DOI: https://doi.org/10.1016/j.jseaes.2020.104231

Reference: JAES 104231

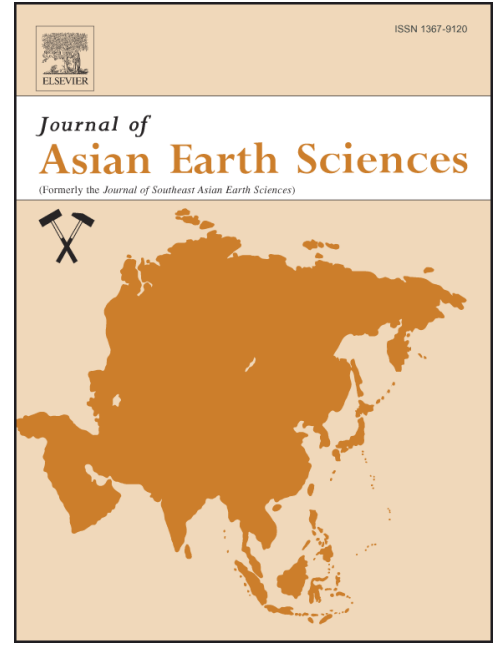

To appear in:

Journal of Asian Earth Sciences

Received Date: 25 March 2019

Revised Date: $\quad 25$ December 2019

Accepted Date: $\quad 4$ January 2020

Please cite this article as: Tran, T.V., Faure, M., Nguyen, V.V., Bui, H.H., Fyhn, M.B.W., Nguyen, T.Q., Lepvrier, C., Thomsen, T.B., Tani, K., Charusiri, P., Neoproterozoic to Early Triassic tectono-stratigraphic evolution of Indochina and adjacent areas: A review with new data, Journal of Asian Earth Sciences (2020), doi: https://doi.org/10.1016/j.jseaes.2020.104231

This is a PDF file of an article that has undergone enhancements after acceptance, such as the addition of a cover page and metadata, and formatting for readability, but it is not yet the definitive version of record. This version will undergo additional copyediting, typesetting and review before it is published in its final form, but we are providing this version to give early visibility of the article. Please note that, during the production process, errors may be discovered which could affect the content, and all legal disclaimers that apply to the journal pertain.

(C) 2020 Published by Elsevier Ltd. 


\section{Neoproterozoic to Early Triassic tectono-stratigraphic evolution of Indochina and}

adjacent areas: a review with new data

Tri Van Tran ${ }^{1}$, Michel Faure ${ }^{2}$, Vuong Van Nguyen ${ }^{3}$, Hoang Huy Bui ${ }^{4}$, Michael Bryld Wessel

Fyhn $^{5}$, Tuan Quang Nguyen ${ }^{4}$, Claude Lepvrier ${ }^{6}$, Tonny B. Thomsen ${ }^{5}$, Kenichiro Tani ${ }^{6}$, Punya Charusiri $^{7,8}$

${ }^{1}$ Vietnam Union of Geological Sciences, 6 Pham Ngu Lao Str., Hoan Kiem Dist., Hanoi, Vietnam. Email: tv_tri@yahoo.com.vn

${ }^{2}$ Institut des Sciences de la Terre d'Orléans, UMR 7327 CNRS Université d'Orléans, Campus géosciences, 1A rue de la Férollerie, 45071 Orléans cedex 2, France.

${ }^{3}$ Faculty of Geology, VNU, Hanoi University of Science, Vietnam.

${ }^{4}$ Vietnam Petroleum Institute. 167 Trung Kinh Str., Yen Hoa Wrd., Cau Giay Dist., Hanoi, Vietnam.

5 Geological Survey of Denmark and Greenland (GEUS), Øster Voldgade 10, 1350Copenhagen K, Denmark.

${ }^{6}$ Department of Geology and Paleontology, National Museum of Nature and Science 4-1-1, Amakubo, Tsukuba-shi, Ibaraki 305-0005

${ }^{7}$ MESA RU, Faculty of Science, Chulalongkorn University, Bangkok, 10330, Thailand.

${ }^{8}$ Department of Mineral Resources, King Rama VI Rd., Bangkok 10400 Thailand.

Keywords: Indochina composite terrane; Sino-Vietnam composite terrane; Paleozoic tectonostratigraphy; Song Ma suture; Tam Ky-Phuoc Son suture 


\section{Abstract}

The Neoproterozoic to Early Triassic tectono-stratigraphic evolution of Indochina and adjacent areas can be divided into six mega-episodes: 1) The Neoproterozoic-Early Cambrian mega-episode was characterized by shallow marine environment in the Sino-Vietnam composite terrane. Meanwhile, the different blocks of the Indochina composite terranes were still separated by branches of the Proto-Tethys. Sino-Vietnam and part of Indochina amalgamated along the Proto-Song Ma suture by the end of the Early Cambrian. 2) During the Middle Cambrian-Early Ordovician mega-episode, shallow shelf carbonate deposition prevailed north of the Proto-Song Ma suture with associated strata containing a rich benthic fauna. This contrasts with deep marine and volcanic arc setting in the south of the Proto-Song Ma suture. 3) The Middle Ordovician-Silurian mega-episode was characterized by subduction of the Tam Ky-Phuoc Son Ocean beneath the Viet-Lao terrane in the north and the Kon Tum terrane in the south. This was followed by a collisional orogeny that sutured the Kon Tum terrane with the Viet-Lao and Viet-Cambodia terranes along the Tam Ky-Phuoc Son suture. The hypothetic Po Ko and Chu Sinh sutures are discussed. The collision led to an intracontinental orogeny in the Sino-Vietnam composite terrane. By the end of the mega-episode, a unified Sino-Vietnam-Indochina super-terrane was established. During the latest Silurian-Early Devonian, benthic fauna and flora of the Sino-Vietnam and Indochina composite terranes shared Cathaysian affinity. 4) The Devonian-Tournaisian mega-episode was characterized by an Early-Middle Devonian transgression and a Late Devonian-Earliest Carboniferous regression, except for parts of northern Indochina where deep marine conditions remained. 5) During the Visean-Middle Permian, the Song Ma ocean reopenned in the north of Indochina. Meanwhile in the west, a volcano-plutonic belt formed due to eastward subduction of the PaleoTethys under the Indochina composite terrane. 6) The Late Permian-Early Triassic mega- 
episode was characterized by Emeishan mantle plume related continental rifting, and the Indosinian orogeny resulting from resuturing of the Indochina and Sino-Vietnam composite terranes along the Song Ma suture.

\section{Introduction}

Indochina constitutes the core of Southeast Asia (Figure 1). It is composed of Gondwana derived crustal fragments that are amalgamated throughout the Neoproterozoic to Early Mesozoic time (Carter et al., 2001; Faure et al., 2014; Fromaget, 1941; Lepvrier et al., 2008; Metcalfe, 2013, 2017). However, Late Paleozoic to Cenozoic tectonism, magmatism and basin development have overprinted and concealed many of the older structures (Faure et al., 2018; Fyhn et al., 2018; Hoang and Flower, 1998; Leloup et al., 2001; Phan and Hoang, 2008; Tapponnier et al., 1990; Tran et al., 2014), and the Neoproterozoic to Early Triassic evolution remains poorly understood.

The extensive Paleozoic and Mesozoic rocks in Vietnam provide a detailed documentation of the paleontological, stratigraphic, igneous, and metamorphic development critical to unravelling the tectonostratigraphic evolution of Indochina and surrounding Southeast Asia (Tran and Nguyen, 1988; Tran and Vu, 2011). This paper integrates existing syntheses of the Neoproterozoic to Early Triassic geologic evolution (Bunopas, 1994; Burrett et al., 2014; Dovjikov, 1965; Faure et al., 2014; Gatinsky and Hutchison, 1986; Hutchison, 2007; Khin Zaw et al., 2014; Lepvrier et al., 2008; Metcalfe, 2013; Ridd et al., 2011; Tong and Vu, 2011; Tran and Vu, 2011; Wongwanich and Burrett, 1983) with recent studies on magmatic and metamorphic dating, detrital zircon analysis, and new paleontological, stratigraphic, structural and tectonic investigations in Vietnam and surrounding areas published both internationally and in native language bulletins (Bercovici et al., 2012; Faure et al., 2018; 
Nguyen X. B. et al., 2015; Usuki et al., 2013; Vu et al., 2000). The presented review is complemented with unpublished radiometric age data from fieldwork in Vietnam, Cambodia and Laos. The integration with the new data sheds light on the Neoproterozoic through Early Triassic stratigraphic and tectonic evolution of Indochina and a revised model for the establishment of Indochina is proposed.

\section{Geological setting and tectonic framework of Indochina and adjacent areas}

Indochina and the adjacent areas consist mainly of continental fragments, orogenic belts, rifted terranes, and obducted oceanic crusts of different ages of formation and amalgamation. Some of them also experienced polyorogenic reworking. These continental blocks derived from Gondwana during the opening and closure of Proto-Tethyan, PaleoTethyan and Tethyan oceans (Burrett et al., 1990, 2014; Metcalfe, 2013, 2017), presently identified as suture zones. These units are the Sino-Vietnam composite terrane (also referred to as the "South China block"), the Indochina composite terrane, and the Sibumasu composite terrane (Figure 1).

\subsection{Sino-Vietnam composite terrane}

The Sino-Vietnam composite terrane consists of the South China region, the northern part of the Hainan Island and part of north Vietnam. It is bounded to the north by the QinlingDabie suture, to the southwest by the Ailaoshan-Song Ma Suture, to the south by the Song Chay-Hainan suture, and its possible eastward extension is concealed underneath the East Vietnam Shelf (Figure 1; Faure et al., 2016). It may be further divided into the Yangtze block and the Cathaysia block, separated by the Neoproterozoic Jiangshan-Shaoxing fault (Charvet, 2013; Faure et al., 2009; Xu et al., 2016). These two blocks were welded together in the Neoproterozoic during the Jiangnan Orogeny (865-820 Ma) (Charvet, 2013; Ren et al., 2013; Shu et al., 2015, Yan et al., 2019). 
In northern Vietnam, the exposed Precambrian basement is attributed to the Hoang Lien Son-Ailaoshan metamorphic terrane (Figure 1). This terrane yields zircon U-Pb SHRIMP ages of $2936 \mathrm{Ma}, 2362 \mathrm{Ma}, 1800 \mathrm{Ma}, 838 \mathrm{Ma}$ and $760 \mathrm{Ma}$ (Tran et al., 2003). Significant Cenozoic left-lateral strike-slip faulting along the Red River shear zone has displaced the North West Vietnam domain to the SE relative to North East Vietnam domain (Figure 1; Leloup et al., 2007; Tapponnier et al., 1990).

\subsection{Indochina composite terrane}

Earlier French geologists used the term "Indosinia" to indicate a large region including much of Vietnam, Laos, Cambodia and the adjacent East Vietnam Shelf (Fromaget, 1941, 1952; Hoffet, 1933; Phan, 1995; Ren et al., 2013; Saurin, 1935). In this paper, the term Indochina composite terrane includes the reworked Precambrian metamorphosed terranes of Phu Hoat, Kon Tum and possibly Pailin, as well as Paleozoic terranes of Viet-Lao, Viet-Cambodia, LoeiPhetchabun, Simao, Sukhothai and East Malaysia (Figure 1). This concept is similar to the "large Indochina terrane" of Burrett et al. (2014). This composite terrane is bounded to the north by the Ailaoshan-Song Ma suture, to the west by the Chiang Rai Line (Sone and Metcalfe, 2008, Wang et al., 2018) that extends southward to the Sra Kaeo suture (Hada, 1999; Wakita and Metcalfe, 2005) and then to the Bentong-Raub suture in East Malaysia (Metcalfe, 2013, 2017). Its eastern boundary is concealed underneath the East Vietnam Shelf.

Several terranes are distinguished within the Indochina block (Figure 1). The Viet-Lao and Viet-Cambodia terranes are composed of folded fossiliferous Paleozoic sediments and igneous rocks. The name Viet-Lao terrane was first used by Gatinsky et al. (1970) and for its most part coincides with the Truong Son terrane used by other authors (Burrett et al., 2014; Lepvrier et al., 2008). The Viet-Cambodia terrane was first established by Faure et al. (2018), and covers southern Vietnam, most of Cambodia and eastern Thailand. The Paleozoic and older rocks in this terrane are mostly covered by Mesozoic strata. The Kon Tum terrane underwent 
polycyclic high grade metamorphism including at least an Early Paleozoic and a Late PermianEarly Triassic event (Faure et al., 2018; Nakano et al., 2007, 2013; Osanai, 2004; Osanai et al., 2008; Owada et al., 2016, 2006; Roger et al., 2007; Usuki et al., 2009, 2013; Vu et al., 2013). The Loei-Phetchabun terrane is composed of Late Ordovician-Triassic sequences deposited in both shallow and deep marine environment (Department of Mineral Resources, 2014). The Sukhothai terrane is mostly composed of Late Paleozoic and Early Mesozoic volcanogenic and arc volcanic sequences. The Simao terrane consists of Paleozoic volcanoclastic sedimentary sequences ranging from Silurian to Permian in age, which are truncated by a Late Triassic unconformity (Wang et al., 2014).

\subsection{Sibumasu composite terrane}

The Sibumasu composite terrane extends from northeast Sumatra, west Malaysia, through west Thailand, Myanmar, and west Yunnan (Figure 1; Barber et al., 2011). The Paleozoic sequence of the Sibumasu composite terrane is floored by Upper Cambrian-Lower Ordovician shallow marine siliciclastic rocks that progressively change upward into SilurianDevonian deep marine fine-grained sediments bearing graptolite and tentaculate. The Carboniferous deposits change from dominantly shallow marine limestone in Baoshan to radiolarian deep-water siliciclastics in NW Malaysia and southern Thailand (Burrett et al., 2016). Early Permian diamictites were deposited, followed by Middle-Late Permian platform carbonate (Burrett et al., 2014; Metcalfe, 2013).

\subsection{Suture zones}

\subsubsection{Song Ma suture}

The NW-SE striking Song Ma zone separates the Sino-Vietnam (S. China) composite terrane to the north from the Indochina composite terrane to the south (Figure 1). It contains ultramafic and mafic mélange assemblages and was documented by French geologists 
(Fromaget, 1941, 1952; Jacob, 1921) under the name of "Thanh Hoa cicatrice." It was recognized later as an ophiolitic suture between the Indochina and Sino-Vietnam composite terranes (Dao and Huynh, 1995, p. 64; Hutchison, 1989, 2007; Ngo and Nguyen, 2016; Tran et al., 1977; Tran and Vu, 2011; Zhang et al., 2013, 2014). The suturing age and subduction polarity remains controversial. There are two main lines of evidence for the age of suturing. Some authors consider the suturing to have occurred between the Silurian and the Devonian (Findlay, 1997; Hutchison, 1989). This view is supported by paleontological evidence (Janvier et al., 1997, 2003; Tong et al., 1996). Most authors favored a Triassic collision prior to the upper Triassic unconformity (Faure et al., 2014; Lepvrier et al., 2004, 2008; Şengör et al., 1988; Tran, 1979). This view is supported by the age of high-pressure metamorphism recorded along the Song Ma suture. Lepvrier et al. $(1997,2004,2008)$ first documented ${ }^{40} \mathrm{Ar}-{ }^{39} \mathrm{Ar}$ ages of 250 245 Ma reflecting shearing along the Song Ma suture zone. Nakano et al. (2008) showed a monazite $\mathrm{U}-\mathrm{Th}-\mathrm{Pb}$ age of $213 \pm 5 \mathrm{Ma}$ for a pelitic gneiss associated with high pressure mafic granulite for this suture zone. Zircon U-Pb SHRIMP dating of Song Ma eclogite yields a similar age of $230.5 \pm 8.2 \mathrm{Ma}$ (Zhang et al., 2013) and U-Pb SHRIMP ages of ultramafic and mafic rocks range from $340 \mathrm{Ma}$ to $310 \mathrm{Ma}$, corresponding to the oceanic crust formation period (Zhang et al., 2014). Based on the Sm-Nd and $\mathrm{U}-\mathrm{Pb}$ isotopic ages of ophiolitic rocks ranging from 387 to 313 Ma, Nguyen V.V. et al. (2013) suggested that oceanic crust formed during the Carboniferous, followed by Late Permian-Early Triassic continental collision between the Indochina and the Sino-Vietnam composite terranes.

\subsubsection{Song Chay suture}

The Song Chay suture was first proposed by Pusharovsky (1965) and Gatinsky et al. (1970). Along the Song Chay fault, an ophiolitic mélange consists of sporadically exposed blocks of serpentinized ultramafic and mafic bodies, Lower Paleozoic limestone, chert and siliceous mudstone enclosed in a sandstone-mudstone matrix (Faure et al., 2014; Lepvrier et 
al., 2011). The age of the matrix is unknown, but cannot be younger than Early Neogene as conglomerate of this age unconformably covers the Song Chay ophiolitic mélange (Lepvrier et al., 2011). The Song Chay suture was previously interpreted as a segment of the AilaoshanSong Chay-Song Ma suture laterally displaced by Cenozoic strike-slip tectonics (Faure et al., 2014, 2016, 2018).

\subsubsection{Tam Ky-Phuoc Son suture}

The E-W striking Tam Ky-Phuoc Son suture consists of metapelite, metapsammite, and paragneiss of Kham Duc and Nui Vu complexes, and metagabbro, amphibolite, serpentinized ultramafic with ophiolitic geochemical affinity (Izokh et al., 2006; Tran et al., 2004; Tran, 1979; Tran and Vu, 2011). It is intersected by the Po Ko suture to the west, but its possible extension in Laos is not clearly defined. The Tam Ky-Phuoc Son suture has been argued to extend to the NW in Laos and merge with the Thakhek-Da Nang fault (Figure 1; Shi et al., 2015; Thassanapak et al., 2018). The exposure of ultramafic bodies, including harzburgite and dunite, along the Da Krong shear zone in Quang Tri province (Nguyen V.T., 1996), as well as a small mafic and ultramafic body in B. Bor, Borikhan district in Laos may lend credence to this argument. The suture zone is considered to represent either an Early Paleozoic ocean separating the Viet-Lao terrane in the north from the high grade metamorphic Kon Tum terrane in the south (Lepvrier et al., 2004; Tran, 1979) or a product of the Indosinian orogeny (Gatinsky and Hutchison, 1986).

Detrital zircon U-Pb ages of $550 \mathrm{Ma}$ from metasandstones from the Kham Duc complex (Usuki et al., 2009), and magmatic zircon ages of $518 \mathrm{Ma}$ and $502 \mathrm{Ma}$ for a trondhjemitetonalite suite (Nguyen et al., 2019) reveal the existence of a Late Neoproterozoic to Early Cambrian Proto-Tethyan ocean between the Viet-Lao terrane and a continental basement preserved as block enclosed in migmatite in the Kon Tum terrane. This complex experienced a poly-cyclic metamorphism during the Early Paleozoic and the Late Permian-Early Triassic. The Early Paleozoic metamorphic evolution is characterized by a HP to MP-LT event, and 
subsequently a LP-HT event with a T climax at ca. 450 Ma (Usuki et al., 2009), followed by ca. 430 Ma magmatism (Tran et al., 2014). The Late Permian-Early Triassic event, which is also characterized by HT (even UHT) conditions, took place between 250 and $236 \mathrm{Ma}$ (Lepvrier et al., 2004, 2008) in a retrograde decompression setting (Nakano et al., 2013; Osanai et al., 2008). More recently Faure et al. (2018) and Owada et al. (2016) argued that the HT metamorphism represented an intraplate event.

\subsubsection{Po Ko suture}

The Po Ko suture strikes N-S along the western margin of the Kon Tum terrane (Figure 1). Ultramafic rocks of the Plei Weik complex occur in the Po Y area within the Neoproterozoic to Early Paleozoic rocks (Lepvrier et al., 2008; Tran, 1998). Banded and serpentinized dunitewehrlite-clinopyroxenite-gabbro complexes typical of ophiolitic assemblage also crop out in this area and extend into southeast Laos and northeast Cambodia (Ha et al., 2009; Tran and Vu, 2011). Ultramafic and mafic rocks in the Po $\mathrm{Y}$ area have N-MORB affinity, and zircon U-Pb LA-ICP-MS age of $459.5 \pm 4.3 \mathrm{Ma}$ (Bui An Nien, personal communication). About $50 \mathrm{~km}$ west of the Po Ko fault in Laos, diorite and rhyolitic rocks were mapped in the Donken area (Figure 1) with whole-rock geochemistry compatible with an island arc setting. These rocks are dated as 477-470 Ma (Early Ordovician) using zircon U-Pb Q-ICP-MS (Gardner et al., 2017). Gardner et al. (2017) interpreted their occurrence to be associated with bivergent subduction of the Tam Ky Phuoc Son ocean under both the Kon Tum terrane and the Viet-Lao terrane.

\subsubsection{Chu Sinh suture}

To the southeast of the Kon Tum terrane, a tectonic mélange composed of metabasalt, metagabbro, serpentinized peridotite, metachert, marble, metagraywacke and metapelite is exposed in a narrow E-W and NW-trending zone south of the Ea Knop town (Figure 1; Nguyen, 1998). It is interpreted as the Chu Sinh suture also referred to as the Ea Kar-Ea Drang suture in Vietnamese literature (Nguyen X. B. et al., 2015). Amphibolite of the complex yield a Sm-Nd 
age of $477 \pm 42 \mathrm{Ma}$ (Nguyen X.B. et al., 2015). This suture is not mentioned in the international geologic literature and requires further investigations.

\section{Review of published data for Indochina and adjacent areas}

In this section, we review the tectono-stratigraphic data of the Sino-Vietnam (South China) and Indochina composite terranes, chronologically ordered into six mega-episodes. For the Sino-Vietnam composite terrane, we focus on the north Vietnam region, with correlations to the southern part of South China.

\subsection{Neoproterozoic - Early Cambrian mega-episode}

In the Neoproterozoic, Indochina and Sino-Vietnam consisted of multiple terranes separated by branches of the Proto-Tethys ocean (see section 2). The Late Neoproterozoic-Early Cambrian sediments in Indochina and adjacent areas are mainly composed of pelitic-mafic volcanic sequences in the lower part and carbonates in the upper part (Figure 2). They unconformably overlie the plutonic-metamorphic basement dated as $755 \mathrm{Ma}$ (Tran, 2003; Tran and $\mathrm{Vu}, 2011)$. An Early Ediacaran age is assigned to this unconformity.

\subsubsection{Sino-Vietnam composite terrane}

North of the Hoang Lien Son-Ailaoshan terrane (Figure 1), the stratigraphy is composed of siliciclastics and dolomite of the Da Dinh Fm. (NP) and siliciclastics, carbonates and phosphatic sediments of the Cam Duong Fm. $\left(\varepsilon_{1}\right)$ (Figure 3). The Cam Duong Fm. contains oncolite fossils such as Medularites dineolatus and Ambigolamellatus horridus, as well as acritarchs such as Archaeohystrichosphaeridium and Barlinella (Pham, 2008). These deposits are distributed in the NW-SE trending Lao Cai phosphate bearing basin, stretching for hundreds of kilometers and unconformably overlying the Hoang Lien Son-Ailaoshan Precambrian basement. They can be correlated to the Dengyng Fm. and Meishucun Fm., respectively, in Yunnan, China (China Geological Survey, 2004; Tran and Vu, 2011). 
Along the Song Ma suture zone, the Nam Co Fm. (Figure 1) consists of metasandstone and metapelite interbedded with thin layers of metabasalt and occasionally with marbles. The formation contains Late Neoproterozoic-Early Cambrian acritarchs and is unconformably overlain by the Middle Cambrian Song Ma Fm. (Tran and Vu, 2011). Detrital zircon U-Pb ages of 850-736 Ma from the Nam Co formation provide a lower bound for its depositional age being younger than the Early Neoproterozoic (Bui V. H. et al., 2018).

In northern Vietnam, the Po Sen complex, distributed in the Hoang Lien Son-Ailaoshan terrane, consists of I-type granodiorite-granite and orthogneiss with typical calc-alkaline affinity, yielding zircon U-Pb SHRIMP ages of $751 \pm 7$ Ma (Tran, 2003; Wang et al., 2011). The Song Chay-Dulong orthogneiss is coeval with the Po Sen granite and yields zircon U-Pb SHRIMP ages of 799-761 Ma (Liu et al., 2006; Yan et al., 2006).

\subsubsection{Indochina composite terrane}

\section{Phu Hoat terrane}

The Phu Hoat terrane (Figure 1), considered as a Late Neoproterozoic-Early Paleozoic microcontinent, consists of gneiss and amphibolite of the Nam Su Lu complex, and gneiss, micaschist, and migmatites of the Bu Khang complex. The Bu Khang complex yields inherited zircon ages from 2540 to $600 \mathrm{Ma}$ (Carter et al., 2001). The S-type granite of the Nam Giai complex with a zircon U-Pb SHRIMP age of $783 \pm 12 \mathrm{Ma}$ is considered an anatectic product of the Bu Khang complex (Nguyen C.D. et al., 2015). Both the Bu Khang and the Nam Giai complexes are strongly affected by Indosinian tectonics as documented by granitic intrusions and metamorphism dated at $249 \pm 5 \mathrm{Ma}$ (Nguyen C.D. et al., 2015).

The Neoproterozoic-Early Cambrian volcano-sedimentary deposits show a clear transition from south to north. To the south, the Kham Duc complex consists of $2600 \mathrm{~m}$ thick of greenschists and tholeiitic basalt interbedded with quartzite, siliceous shale, and bedded 
limestone. To the north, the Suoi Mai Fm. consists of fine grained quartzite interbedded with biotite-chlorite phyllite that overlies the Bu Khang complex across a possible unconformity.

\section{Kon Tum terrane}

The amphibolite to greenschist facies metamorphic rocks of the Kon Tum terrane are attributed to the Late Neoproterozoic-Early Cambrian Nui Vu complex. They were derived from organic-rich claystone, chert, as well as andesitic basalt and calc-alkaline effusive protoliths (Figure 2; Tran and $\mathrm{Vu}, 2011$, p. 398). Enclosed in the Nui Vu complex, blocks of metamorphosed mafic-ultramafic rocks, 518-502 Ma trondhjemite-tonalite (Nguyen et al., 2019), chert and marble belonging to the Hiep Duc ophiolite assemblage form a tectonic mélange. Metagabbro of the Phu My complex and inherited zircon from Kan Nack complex yielded ages of $678 \pm 23 \mathrm{Ma}$ (Osanai, 2004) and $1404 \mathrm{Ma}$ (Nam et al 2001), respectively.

\section{Pailin terrane}

In western Cambodia and southeast Thailand, the Pailin terrane consists of mylonitized quartzo-feldspathic gneisses, amphibolites, and migmatites exposed in a ca. $40 \mathrm{~km}-$ long SEtrending belt (Figure 1; Gubler, 1935; Kun and Say, 1986). However, the significance of this terrane is still poorly understood.

\subsection{Middle Cambrian-Early Ordovician mega-episode}

Middle Cambrian - Early Ordovician sequences were deposited on the Yangtze-Hoang Lien Son-Ailaoshan, the Viet-Lao, the Viet-Cambodia terranes, and the Sibumasu composite terrane over the early Middle Cambrian unconformity. These series are composed of terrigenous and carbonate sediments deposited on a continental shelf (Figure 2). 


\subsubsection{Sino-Vietnam composite terrane}

\section{North East Vietnam}

In the North East Vietnam domain, the Middle Cambrian-Early Ordovician sequence includes the Ha Giang, Chang Pung and Lutxia Fms. to the NW and the Than Sa Fm. to the SE (Figure 3). The Middle Cambrian Ha Giang Fm. is composed of terrigenous sediments with carbonate interbeds (Figure 4A). The formation is rich in fossils such as trilobites (Figure 5) and brachiopods (Pham, 2008, pp. 21-26; Tran and Vu, 2011, p. 54), representing shallow marine fauna that closely resembles Early Paleozoic marine fauna in South China (Tong and Vu, 2011, pp. 9-10). In addition, the Ha Giang Fm. also includes interbeds of metabasalt, metaandesite and porphyroid, which are exposed around the periphery of the Song Chay massif. Geochemical analysis suggests that these interbeds represent intra-plate basalts (Tran and Vu, 2011, pp. 226 \& 398). Further up section, the Late Cambrian Chang Pung Fm. (Figure 4B) and Early Ordovician Lutxia Fm. (Figure 3) are composed of carbonates interbedded with argillaceous shale, siltstone and sandstone containing abundant shallow marine trilobites and brachiopods (Chang Pung Fm.: Blackwelderia-Paralorenzella, Chuangia, Irvingella, Billingsella tonkiniana, Prosaukia, Calvinella; Lutxia Fm.: Isotelus stenocephalus, Pseudokainella sp.) (Pham, 2008, pp. 104-106). Enclosed within the Ha Giang Fm. are the Nam But ultramafic complex, Bach Sa gabbroid and 470 Ma Thanh Long plagiogranite (Bui, 2010, p. 119).

To the SE of North East Vietnam, the rhythmic terrigenous sediments of the Middle Cambrian-Early Ordovician Than Sa Fm. contain agnostid trilobites, including the Cambrian Lotagnostus-Agonostus zone and Hedinaspis-Charchaqia-Niobella beds in the lower part (Pham, 2008, pp. 123-126). The deposits grade upward into Tremadocian black shale bearing graptolite such as Tetragraptus aqqroximatus N., T.acclinans, Expansograptus constrictus (Rushton et al., 2018). The fauna could be the correlative of that in the Huangdongkou Fm in 
the Jiangnan belt in South China (Figure 1). Such fauna assemblages are indicative of a relatively deep depositional environment and suggests an interconnection with the JiangnanChukiang (South China) and NE Australia basins (Shergold, 1995).

\section{North West Vietnam}

In the North West Vietnam domain, the Middle Cambrian-Early Ordovician sequence, including the Song Ma, Ham Rong and Dong Son Fms., are exposed on the NE side of the Ma River (Figures. 2\&3). Lying unconformably on the Nam Co Fm., the Middle Cambrian Song Ma Fm. has a consistent thickness of about $650 \mathrm{~m}$ and consists of a basal conglomerate $(30 \mathrm{~m}$ thick) that transitions upward to quartz-sericite schist, metabasalt, black shale and calcareous shale. The formation yields brachiopods such as Lingulella sp., Obolus sp., and trilobites such as Solenoparia sp., Cyclolorenzella cf. Parabola, Anomocarina? sp., Pseudagnostus douvillei. Further up section, the Late Cambrian-Early Ordovician Ham Rong Fm. consists of oolitic dolomitic limestone interbedded with marly shale and sandstone that contain abundant trilobites (Dreparura premesnili, Damesella brevicaudata, Calvinella walcotti) and brachiopods (Billingsella tonkinesis) (Pham, 2008, pp. 107-115). They grade upward into terrigenous coarse-grained sediments of the Early Ordovician Dong Son Fm., bearing trilobites such as Asaphopsis jacobi, Asaphellus trinodosus, and Annamitella asiatica (Dovjikov, 1965, pp. 169170). These Middle Cambrian to Early Ordovician fauna suggests a continental shelf setting (Pham, 2008). Situated farther to the NE, along the Da River, the Ben Khe Fm. (Figures. 2\&3) consists of flyschoid terrigenous sediments with calcareous shale interbeds (Tran and Vu, 2011, p. 57).

\subsubsection{Indochina composite terrane}

To the north and west of the Kon Tum terrane, the Viet-Lao and Viet-Cambodia terranes contain terrigenous-volcanogenic sediments of the A Vuong Fm. It rests unconformably on the 
Kham Duc and Nui Vu complexes and is unconformably overlain by the Long Dai Fm.

(Figures. 2\&3). The formation consists of quartz-muscovite-sericite schist, siliceous schist, felsic effusive, banded dolomitic marble, actinolite-epidote schist and black shale (Nguyen, 1995, 1997; Tran, 1998). The black shale contains Tremadocian (Early Ordovician) planolites and graptolites (Acanthograptus sinensis, A. macilentus, Dictyonema asiaticum) (Nguyen, 1995, 1997; Pham, 2008, p. 131). Further southwest, in Stung Treng (northeast Cambodia), Middle Cambrian-Early Ordovician quarzitic sandstone and calcareous siltstone contain trilobites such as Asaphiscus aff. Gregarious (=Balainia aff. gregaria) (Pham, 2008; Saurin, $1935,1956)$.

Within the Kon Tum terrane, low grade metamorphosed volcano-terrigenous deposits of black shale, black cherty shale and quartzitic sandstones interbedded with dolomitic limestone, porphyritic andesite, metabasalt and metarhyolite are attributed to the Middle Cambrian-Early Ordovician Phong Hanh Fm. (Tran, 1998, Tran and Vu, 2011, p.60). The formation rests unconformably on supposed Neoproterozoic metamorphics, which are intruded by 470-418 Ma granodiorite of Dien Binh Complex. Fossiliferous Devonian sediments cover the Phong Hanh Fm. (Figure 2).

\subsection{Middle Ordovician-Silurian mega-episode}

This mega-episode is characterized stratigraphically by flyschoid and volcano-clastic sedimentation in both the Sino-Vietnam and Indochina composite terranes. These deposits unconformably overlie the Middle Cambrian-Early Ordovician rocks (Tran and Vu, 2011).

\subsubsection{Sino-Vietnam composite terrane}

In the Cathaysia and Yangtze blocks in both South China and north Vietnam, the Late Ordovician stratigraphic records indicate a shallowing upward of the sedimentary facies, changing from deep-marine graptolitic shales to shallow-water, coarse grained clastic rocks 
(Shu et al., 2015; Tran and Vu., 2011). These deposits are capped by an Early Devonian angular unconformity. In South China, Silurian deposits are only found in the Qin-Fang region (Figure 1) where more than $9 \mathrm{~km}$ of Silurian-Early Devonian siliciclastic rocks are overlain unconformably by Middle Devonian deposits (Zhang et al., 2018).

\section{North East Vietnam}

In North East Vietnam, a similar paleo-environment pattern to that of South China occurred during the Late Ordovician-Early Silurian. In the Thai Nguyen province, the MiddleLate Ordovician $\mathrm{Na}$ Mo Fm. consists of neritic sandstone, shale, and siltstone containing trilobites such as Remopleurides taliangenis, Synhomalonotus birmanicus and coral such as Plasmoporella sp. Conformably overlying the Na Mo Fm., the Phu Ngu Fm. consists of finegrained terrigenous sediments, containing graptolites such as Climacograptus latus, Cl. cf. scolaris, Dictyonema sp., Diplograptus sp., Ptilograptus sp., Glyptograptus sp. and trilobites such as Agnostus perrugatus, Remopleurides salteri of Late Ordovician-Wenlock age. In the Quang Ninh province, the Tan Mai and Co To Fms. (Figures. 2\&3) consist of turbiditic tuffaceous gritstone, siltstone, and sandstone (Figure 6A-C) interbedded with black shale containing Early Silurian graptolite (Spirograptus turriculatus, Campograptus communis, Monograptus priodon, Demirastrites triangularis) (Tran and Vu, 2011, pp. 60-62). On the Co To island, excellent outcrops of Late Ordovician-Early Silurian rocks with a youngest peak detrital zircon U-Pb of $440 \mathrm{Ma}$ (Rizzi et al., 2020) show slope to deep-water turbiditic facies (Figure 6A-C; Bui H. H. et al., 2018).

Late Silurian deposits in North East Vietnam are only found south of Hai Phong City (Figure 1) and are attributed to the Kien An Fm. (Figure 3). It consists of blue-gray marl, mudstone, sandstone and limestone lenses containing brachiopods (Retziella webery, Eospirifertingi) and corals (Favosites mamilatus, Nipponophyllum nikolaevae), signifying a 
shallowing upward trend from the deep-water Early Silurian deposits (Tong and Vu, 2011, pp. 91-92).

\section{North West Vietnam}

In North West Vietnam, Late Ordovician-Early Silurian deposits lie unconformably on older rocks and are attributed to the Sinh Vinh Fm. to the NE and the Ket Hay Fm. to the SW (Figure 3). The Sinh Vinh Fm. consists of basal conglomerate and coarse-grained arkosic sandstone grading upward into light gray, thickly bedded dolomitic limestone, sandy limestone and marl containing abundant corals (Plasmoporella kiaeri, Favosites aff. Forsberi, Favositella alveolatus, Parastriatopora sp.) and crinoids (Tran and Vu, 2011, p. 62). This indicates a shallow marine environment, similar to that over the Yangtze Block and in sharp contrast to the coeval deep-water environment in North East Vietnam. Grading upward, the Bo Hieng Fm. (Figures. 2\&3) consists of marly shale and limestone with corals, brachiopods and bivalves similar to those found in South China and Eastern Australia (Tong and Vu, 2011).

To the north of the Song Ma suture, the Ket Hay Fm. dominantly consists of deep-water shale and cherty shale containing Late Ordovician graptolites such as Rastrites sp., and further up section Demirastrites triangulatus, Hedrograptus cf. rectangularis, Diplograptus cf. modestus of Llandovery age (Tong et al., 2013; Tran and Vu, 2011, pp. 62-63). The lithological and fossil assemblages of the Ket Hay Fm. are similar to the Song Ca Fm. in the Viet-Lao terrane.

\subsubsection{Indochina composite terrane}

During the Early-Middle Ordovician, arc-affinity volcanism was distributed from western Kon Tum to northern Laos in a NW-SE trend. In Donken, SE Laos (Figure 1), calcalkaline and tholeiitic magmatism with volcanic arc affinity crops out west of the Po Ko suture. Diorite and rhyolitic tuff yields zircon $\mathrm{U}-\mathrm{Pb}$ ages of $470 \pm 2 \mathrm{Ma}$ and $476 \pm 1.5 \mathrm{Ma}$, respectively 
(Gardner et al., 2017). West of Quang Binh province near the Vietnam-Laos boundary, arcaffinity calc-alkaline granodiorite and granite of the Vit Thu Lu complex with zircon U-Pb age of $475 \pm 5$ Ma intruded into the Long Dai Fm. (Figures. 2\&3; Bui, 2010, p. 58; Le D.B. and Bui M.T., 2008). Within the Kon Tum terrane, I-type granodiorite of the Dien Binh complex displays zircon $\mathrm{U}-\mathrm{Pb}$ isotopic ages of 470-468 Ma in the Po Y area (Nguyen et al., 2018), 445 Ma in the Tra Bong area (Nguyen et al., 2015), and $444 \pm 17$ Ma and $451 \pm 3 \mathrm{Ma}$ in the Dien Binh area (Carter et al., 2001; Nagy et al., 2001). S-type granitic intrusions of the Chu Lai Complex yield zircon U-Pb LA-ICP-MS ages of 444-426 Ma (Dinh, 2017), and the Dai Loc Complex yield ages from 427 to $406 \mathrm{Ma}$ (Carter et al., 2001; Pham et al., 2016). The Huoi Tong massifs in west Dien Bien (Figure 1) are dated as 446-415 Ma (Nguyen V. N. et al., 2005).

Deposits of the Middle Ordovician to Silurian mega-episode are found both in the VietLao and Viet-Cambodia terrane, characterized by two distinct successions: the Middle Ordovician-Early Silurian is dominated by deep-marine fine-grained sediments while the Late Silurian is characterized by a depositional environment changing from shallow to deep-water. During the Middle Ordovician-Early Silurian, deep-water environment is recorded by the Song Ca Fm. and Long Dai Fm. in the north and south, respectively. The Song Ca Fm. is about 2000 $m$ thick and is distributed north of the Song Ca Fault. It consists of Early Silurian graptolitebearing shale, fine-grained sandstone and some bedded limestone interbedded with $440 \mathrm{Ma}$ rhyolite (Tran Trong Hoa and T. Usuki, personal communication). The Long Dai Fm. is about 2000-2500 m thick and extends from north and west of the Kon Tum terrane to northern Central Vietnam and northeast Laos (Nguyen, 1997; Phan et al., 2009). Resting unconformably on the A Vuong Fm., it consists of a basal conglomeratic unit (70 - 90 m thick) and coarse-grained graywacke sandstone in the lower part (Figure 6D-F), and pass upward into Late Ordovician trilobite-bearing siltstone, sandstone, striped cherty shale, and Llandovery-Wenlock radiolarian and graptolite-bearing black shale (Dovjikov, 1965, pp. 210-212; Nguyen V. P., 2000; Tran 
and $\mathrm{Vu}, 2011$, p. 64). Interbeds of intermediate to felsic volcano-clastic rocks are also recognized. The sandstone contains fragments of felsic and mafic effusives, crystalline schist and granite, and its composition indicate a volcanic arc origin (Yoshida et al., 2002). The volcanic beds can also be correlated to similar deposits in Laos (Thassanapak et al., 2017).

During the Late Silurian, the deep-water depositional environment of the Song Ca Fm. and lower Tay Trang Fm. persisted in the northwest, while to the south the shallow marine siliciclastics of the Dai Giang Fm. (Figures. 2\&3) dominated, containing a rich benthic fauna such as trilobites, corals, bivalves, and fishes (Tong et al., 2013). However, in the Sepon mine, Laos (Figure 1), Ludlow-Pridoli radiolarian cherts indicate basin deepening toward the southwestern margin of the Viet-Lao terrane (Thassanapak et al., 2017).

\subsection{Devonian-Early Carboniferous (Tournaisian) mega-episode}

In the Late Silurian- Early Devonian, orogenic-type batholitic intrusions formed in both the Indochina and Sino-Vietnam composite terranes outlined by the Dai Loc complex in VietLao terrane and 428-415 Ma Song Chay complex in North East Vietnam (Roger et al., 2000; Yan et al., 2006). Devonian-Early Carboniferous sedimentary deposits in the Sino-Vietnam composite terrane and north Central Vietnam are characterized by shallow marine facies containing a rich benthic fauna (Duong, 1980; Tong et al., 2013). Along the western margin of Indochina, volcanic rocks in the Loei-Phetchabun terrane were dated as 349-304 Ma (Qian et al., 2016), while in the Kon Tum terrane a thermo-tectonic event was recorded at 360-340 Ma (Nagy et al 2001) and 366 Ma (M. Faure and Nguyen V.V., unpublished data). Fyhn et al. (2019) illustrated a 340 Ma peak in detrital zircon age spectrum in modern rivers draining the northern Kon Tum terrane and interpreted the zircons to imply the existence of unmapped Late Devonian-Early Carboniferous intrusions in this region similar to farther west. 
The lowermost Devonian, consisting of nearshore gritstone and sandstone, rests unconformably on older rocks in the Sino-Vietnam composite terrane (Tran and Vu, 2011, p. 70; Xu et al., 2016), on Silurian rocks in Viet-Lao terrane, and even on granite in the western margin of the Kon Turn massif (Tong et al., 2013). In the North East Vietnam domain, the lower part of the Song Cau Group (Figure 3) contains fossil flora of Taeniocrada (?) sp., Eospecia gracious, Buthotrephis, antiquata and vertebrate remains of Yunnanolepis sp. (Tran et al., 1977, p. 73) while in the North West Vietnam domain, the Bo Hieng Fm. (Figure 3) contains Taeniocrada sp. (Ta and Le, 1996). Plant fragments as well as arthropod and fish remains are also found in the Do Son Group in the Hai Phong area (Figure 7A; Janvier et al., 2003; Long et al., 1990) and on the Ngoc Vung island, ESE of Ha Long Bay (Figure 1). Some authors argue that the Do Son Group may include the upper most part of the Silurian (Gonez et al., 2012; Janvier et al., 2003), and the plant fragments found on the Ngoc Vung island (Figure 1) represents the earliest known flora of the Sino-Vietnam composite terrane (Gonez et al., 2012).

Lower Devonian deep-water deposits belonging to the Song Mua Fm. and part of the Tay Trang Fm are limited to a few areas. The Song Mua Fm. is distributed along the Da River basin in North West Vietnam, consisting of predominantly black argillaceous shale up to 2300 m thick (Dovjikov, 1965). The Tay Trang Fm. is distributed along the Ca River basin in north Central Vietnam (Figure 1) and contains both deep and shallow water deposits juxtaposed laterally. The formation's deep-water facies consists of shale and siltstone bearing graptolite (Monograptus zonoformis, M. praehercynicus, M. cf. aequabilis notoaequabilis, M. thomasi) and coniconchs (Nowakia acuaria, N. elegans, Styliolina intermedia, etc.) while shallow water facies contains crinoids (Schyschcatocrinus sp., Cyclocyclicus sp., Anthinocrinus floreblus, etc.) as well as fossil flora in NW Ha Tinh near the Viet-Lao border (Zosterophyllum sp., Hostimella sp., Protoleiosphaeridum angulatum) (Dovjikov, 1965, p. 191; Tran et al., 1977). 
The Tay Trang Fm. may include some of the latest Silurian at its base (Tong and Vu, 2011; Tran and $\mathrm{Vu}, 2011)$.

The Middle and Upper Devonian consist of interbedded siliciclastics, carbonates and chert. The maximum Devonian transgression took place in the Givetian as shown by a large distribution of shallow water carbonate containing abundant bioherms and reef corals as well as conodont-bearing cherty deepwater facies (Figure 7B; Tong et al., 2013). In addition, in some places there are coal-bearing successions reflecting a transitional depositional environment ranging between marine influenced continental and shallow marine, such as the Middle Devonian Dong Tho Fm. distributed over a small part of northern Central Vietnam. This formation has a thickness of $1050 \mathrm{~m}$, and consists mainly of sandstone, anthracite and coaly shale containing fossil flora such as Protopteridium sp., Lepidodendropsis $\mathrm{sp}$. and brachiopods such as Emanuella tumida, Chonetes sp., Undispirifer rudiferus (Dovjikov, 1965, p. 227; Tong and $\mathrm{Vu}, 2011$, pp. 196-198; Tran et al., 2016).

Along the southwest Vietnam and Cambodian margin towards the Gulf of Thailand, Devonian deposits of the Hon Heo Fm. consist of sandstone and siltstone interbedded with argillaceous shale containing flora remains (Taeniocrada (?) sp. and Psilophyton sp.) (Figure 3; Nguyen N.H., 1996).

Upper Devonian deep-water deposits are attributed to the Ngoc Lam Fm. in NW Quang Binh province (Ta, 1998) and Thien Nhan Fm. in Ha Tinh province. They contain rich pelagic faunas including tentaculitoids such as Striatostyliolina striata and Styliolina sp., and radiolarians such as Entactinia cometes, Belowea variabitis, and Archocyrtium (Nguyen et al., 2016). They grade upward into Tournaisian sediments containing the conodonts Polygnathus fornicates and Gnathodus semiglaber (Nguyen B. M. et al., 2013). In addition, deep marine deposits are also found in North West Vietnam (Toc Tat and Da Nieng Fms. (Doan and Ta, 2003)) and North East Vietnam (Lung Nam and Pho Han Fms.; Figure 7B), which contain 
forams such as Uralinella bicamerata, Eoendothyra communis, Quasiendothyra konensis and is rich in conodonts such as Palmatolepis gracilis, P. sigmoidalis, Spathognathodus disparilis (Tran and Vu, 2011). Similar radiolarian-bearing cherty deposits occur in central Laos and the Loei region of NW Laos (Udchachon et al., 2015, 2017).

\subsection{Carboniferous (Visean)-Middle Permian mega-episode}

Over the interior of Indochina as well as within the Sino-Vietnam composite terranes, carbonate platform developed widely resulting in deposition of thick and homogeneous carbonate successions that rest unconformably on Devonian-Tournaisian formations (Tong and Vu, 2011, p. 230; Tran and Vu, 2011, pp. 99-102). In addition, Serpukhovian coal-bearing sediments in Central Vietnam, southern Laos, NE Thailand and Cambodia are also found resting unconformably on Devonian and Tournaisian-Early Visean strata (Ha et al., 2009; Hoffet, 1933). These sediments were deposited in terrestrial swamps and paralic environment (Tran et al., 2016; Ueno and Charoentitirat, 2011). Meanwhile, volcanic series roughly of the same age were widespread in the western margin (Sukhothai arc, Loei-Phetchabun belt, northern Cambodia, central and southwest Vietnam).

\subsubsection{Indochina composite terrane interior (NE Vietnam-N Laos-NE Thailand)}

The Carboniferous-Middle Permian deposits in this area (Figure 8) are dominated by continental shelf carbonates. The Bac Son Fm. consists largely of about 800-1000 m thick of limestone and dolomite with chert interbeds and lenses, bearing Early Carboniferous-early Late Permian brachiopods, corals and foraminifera (Nguyen, 1985). In NW Laos, along the Nam Ou, Nam Tha River as well as in Luang Prabang, west Vientiane and in northern part of northeast Thailand, the Late Carboniferous-Permian consists of thinly bedded shale and limestone bearing fossils such as Schwagerina princep; Pseudofusulina gigantea, P.jappnica, coaly-shale bearing Cathaysian-affinity plant fossils such as Carbonicola, Gigantopteris 
nicotinae foliae, Pecopteris arcuata, as well as andesite tuffs and siltstone (Saurin, 1956). In SW Vietnam and southern Cambodia, the Early-Middle Permian Ha Tien Fm. consists mainly of limestones containing abundant Parafusulina loeyensis and Codonofusiella sp. (Figure 9).

Early Carboniferous coal-bearing swamp sediments occurred in Salavan, Attapeu and NW of Vientiane in Laos (United Nations, 1990); and in Sisophon, Kratie, Peam Pros, Bos Dambang, and Kampot in Cambodia (Fontaine and Workman, 1978; United Nations, 1993); as well as in La Khe in north Central Vietnam, and in the northern part of northeast Thailand (Rattanasathien, 2011). In Salavan, SE Laos, resting unconformably on Early Famennian limestone, the sediments have a thickness of 300-400 $\mathrm{m}$ and consist of a thick basal conglomerate, grading upward into sandstone, black-grey calcareous siltstone, and anthracite seams (Ha et al., 2009; Tran, 2000). They yield abundant Late Visean-Early Serpukhovian plant fossils such as Stigmaria rugulosa, Pecopteris aspera, Calamites cf. sukowi, Lepidophyllum trigeminum of Cathaysian affinity and bivalves such as Aviculopecten cf. dupontesi, Astartella lutungini (Ha et al., 2009; Hoffet, 1933; Saurin, 1956). In the Na Duang coal mine in Loei province in NE Thailand, conglomerates, tuffaceous sandstone and coaly shale contain abundant basal Bashkirian terrestrial plant remains such as Stigmaria ficoides, Lepidodendron timsuwanii, Eusphenopteris sp., Adiantites sp. These plant fossils have similarities to the South China floras (Laveine et al., 2009, Rattanasathien, 2011).

\subsubsection{Western Indochina margin (NE Thailand, NW Vietnam-Laos-Cambodia-SW Vietnam)}

The Latest Carboniferous-Early Permian intermediate volcanic series and I-type granitoids are distributed around the western periphery of the Indochina composite terrane (Figure 8). They are found along the Vietnam-Laos border (Bui, 2010), in the Siem Riep-Stung Treng region in Cambodia, in the Loei-Phetchabun, Lampang, Chanthaburi and Sra Kaeo volcanic belts in Thailand (Barr and Charusiri, 2011; Charusiri et al., 2002; Salam et al., 2014; 
Sone et al., 2012) and in the Kuantan-Sungei Lembing region in eastern Malaysia (Burrett et al., 2014; Hutchison, 2007; Metcalfe, 2013).

In western Indochina and SW China, the Carboniferous-Early Permian volcanic rocks consist of various compositions of andesites, dacites and basalts. The basaltic rocks in the central Loei area were linked to ocean-floor and ocean-island, while calc-alkaline porphyritic andesite and associated plutonic rocks in Wang Pong area formed above an east-dipping subduction zone underneath Indochina (Barr and Charusiri, 2011; Charusiri et al., 2002; Pham and Ta, 2003). The continuation of the Loei belt in NW Laos contains 349-330 Ma andesitic, rhyolitic and tuffaceous deposits, as well as $\sim 315$ Ma basalts and andesites of continental arc affinity (Qian et al., 2015). In the Sukhothai arc, Late Carboniferous-Permian volcanosedimentary successions of limestones, sandstones, shales and chert are interbedded with felsic to intermediate volcanic rocks. An Early Permian age is indicated by the presence of fusulinids (Pseudoschwagerina sp.), and radiolaria (Pseudoalbaillella simplex, P. lomentaria, $P$. scalprata) as well as stratigraphic relationship with over- and underlying rocks (Ueno and Charoentitirat, 2011).

In North West Vietnam, the Early Permian volcano-sedimentary Song Da Fm. is distributed mainly along the right side of the Da River (Lai Chau and Dien Bien provinces) (Figures. 8\&9; Dovjikov, 1965, pp. 198-200). It is composed of $280 \mathrm{~m}$ thick of conglomerate, gritstone, and sandstone interbedded with siltstone and shale. Upward, it grades into $350 \mathrm{~m}$ thick of andesitic basalt, felsitic dacite, thin-bedded cherty shale, and limestone. The upper part is composed mainly of $700 \mathrm{~m}$ thick of bedded limestone containing Pseudofusulina sp. Misellina ovalis of Early Permian age interbedded with tuffaceous shale and marly shale (Tran and $\mathrm{Vu}, 2011$, pp. 245-247). In the SE, the I-type gabbrodiorite, granodiorite, and granite of the Dien Bien Phu Complex intrude the volcano-sedimentary beds of the Song Da Fm. The 
granitoids yield zircon U-Pb LA-ICP-MS ages ranging from 281 to $272 \mathrm{Ma}$ (Liu et al., 2012; Tran and Nguyen, 2006).

In NW Laos, the Early Permian Houayxay Fm. consists of dacite, rhyolite, and tuff conglomerate containing brachiopod (Strophomerida indet., Lingula sp., Schuchertellidae gen. indet., Productida fam. gen. indet.). The volcanic rocks have similar lithological and geochemical characteristics to that in the Houayxay gold mine, yielding a zircon U-Pb LA-ICPMS date of $286 \pm 4$ Ma (Early Permian) (Manaka et al., 2014). In southern Laos, continental arc magmatism during the Early Permian is documented at the Sepon gold mine, characterized by ca. 295-288 Ma U-Pb LA-ICP-MS ages (Khin Zaw et al., 2014).

Along the Vietnam-Laos border (Vit Thu Lu, Quang Binh province), the Dong Toan Fm. consists of tuff-andesite, andesitic basalt, and andesite interbedded with clastic sediments. Its age is based on the occurrence of Carboniferous-Permian corals and crinoids and Late Permian brachiopod as well as the stratigraphic relation to underlying Middle Permian carbonates. Their geochemical characteristics are compatible with subduction-related island arc magmatism or an active continental margin setting (Bui, 2010, p. 70).

In the Srepok River Basin near the Vietnam and Cambodia border, the Dak Lin Fm. is composed of intercalating thin bedded cherty shale, porphyritic andesite, andesitic basalt, rhyodacite, tuffs, and limestone that contain Schwagerina sp., Pseudofusulina sp., Verbeekina sp. of latest Carboniferous-Early Permian age (Tran, 1996). These volcano-sedimentary sequences extend into NE Cambodia. Volcano-sedimentary sequences of Late Carboniferous-Permian age are also indicated in the Siem Riep-Stung Treng region of Cambodia (United Nations, 1993). In addition, diorites, granodiorites, and granites of the Ben Giang-Que Son complex exposed in the Kon Tum metamorphic terrane yield zircon U-Pb ages around 303-295 and $261 \mathrm{Ma}$ (Nguyen and Tran, 2016). These igneous rocks show high LILE enrichment relative to HFSE, 
high LREE and low HREE (Figure 10), which are typical of island arc and active continental margin (Bui M.T., 2010; Tran et al., 2005).

Offshore Cambodia and SW Vietnam, on the Hon Mau, Hon Chuoi, Hon Buong and Nam Du islands (Figures. 8\&9), thinly bedded andesitic and rhyodacite tuffs of the Nam Du Fm. are dated by zircon U-Pb LA-ICP-MS at around 279 Ma (Early Permian) (Fyhn et al., 2016). The formation also contains turbidite and cherts bearing Late Carboniferous radiolaria. These grade laterally into Early-Middle Permian siliciclastics and limestones of the Ha Tien Fm. dated by brachiopods and foraminifera assemblages. The age of the Nam Du Fm. is further constrained by the overlying Middle-Late Permian Dat Do Fm. containing Beecheria sp. and Neospirifer sp. (Tran and Vu, 2011).

\subsection{Late Permian-Early Triassic mega-episode}

Late Permian volcano-sedimentary rocks are exposed widely in north Vietnam and south China but more scattered in other areas of the Indochina peninsular. They rest unconformably upon older rocks. A number of volcanic rift systems developed in north Vietnam, including the Song Da, Tu Le, Song Hien, and the An Chau rift systems (Figure 8). The volcanic deposits of the Song Da-Tu Le rift systems are assigned to the Cam Thuy Fm., which consists of porphyritic high titanium basalt, ferrous allite, and tuffaceous siltstones (Figure 9), dated as $255 \mathrm{Ma}$ (Tran et al 2016). Meanwhile, igneous rocks in the Song Hien rift ranges in composition from ultramafic-mafic to felsic, dated as 266-260 Ma (Izokh et al., 2005; Tran et al., 2008). In addition, widespread 260-248 Ma anatectic S-type granites occurs in the Viet-Lao terrane (Figure 8; Shi et al., 2015; Tran and Vu, 2011).

In NE Vietnam and Battambang-Sisophone (Cambodia), a regional uplift triggered the karstification of the Carboniferous-Permian limestone and led to coal and bauxite deposition 
(Tran and Vu, 2011; United Nations, 1993). In NE Vietnam, bauxites are found at the base of the Dong Dang Fm., which consists mainly of thinly bedded limestone, shale, and cherty limestone containing Changhsingian fusulinids (Palaeofusulina prisca, Colaniella parva, Reichelina pulchra) as well as brachiopods and calcareous algae (Nguyen, 1985; Tran and Vu, 2011, pp. 107-108).

Late Permian coal-bearing deposits are scattered throughout north Vietnam, NW Lao and SW Cambodia. In the Song Da rift, the Yen Duyet Fm. (Figure 9) overlies volcanosedimentary beds and consists of carbonaceous shales, coal seams, and limestones. It contains leaf imprints such as Gigantopteris nicotianaefolia, Lobatannularia multifolia, Pecopteris anderssonii, Taeniopteris multinervis (Nghiem, 2018; Nguyen, 1984) and Late Permian brachiopods such as Leptodus sp., Oldhamina cf. decipiens, Neophricodothyris cf. asiatica. Further to the southwest in NW Lao (Nam Ou) and NE Cambodia, Late Permian coal occurs in the form of thin lenses (Fontaine and Workman, 1978; United Nations, 1990, 1993). In addition, in Luang Prabang, NW Laos, Cathaysia-affinity Dicynodon cranial and postcranial elements are found in the Purple Claystone Fm. (Luang Prabang Fm.), indicating a land connection between the Indochina and Sino-Vietnam composite terranes (Bercovici et al., 2012). Middle to Late Permian Cathaysian affinity flora are also found in this area, such as Sphenopteris taiyuanensis, Lobatannularia ensifolia, Gigantonoclea sp., Rajaia guizhouensis (Bercovici et al., 2012).

\section{New zircon U-Pb data}

In addition to the review of published literature, we have carried out field surveys to refine geological boundaries, as well as taken samples in various terranes in Indochina and the surrounding areas. 


\subsection{Sampling and analytical methods}

In this section, we describe briefly the locations, zircon features from cathodoluminescent images and the results of U-Pb dating by LA-ICP-MS method for 16 samples (Table 1 and Appendix 1). The analyzed samples are from unmetamorphosed, mostly felsic to sub-alkaline volcanic and plutonic rocks, except for sample OG9 collected from a gabbro. Zircon $\mathrm{U}-\mathrm{Pb}$ geochronology was carried out on mineral separates embedded in epoxy mounts by laser ablation inductively coupled plasma mass spectrometry (LA-ICP-MS) following the standard procedures at the Geological Survey of Denmark and Greenland (GEUS), Kyushu University, Japan, the Geological Survey of Japan (AIST) and Institute of Earth Sciences, Academia Sinica, Taiwan (IESAS). The cathodoluminescent images of analyzed zircon minerals show euhedral shape (Figure 11).

\subsection{Zircon geochronological results}

Calculation of errors and correlation of the ${ }^{206} \mathrm{~Pb} /{ }^{238} \mathrm{U}$ and ${ }^{207} \mathrm{~Pb} /{ }^{235} \mathrm{U}$ ratios follow the procedure of Ludwig (2008) using the program ISOPLOT 4.15. The concordia diagrams for the analyzed samples are shown on Figure 11. The detailed analysis data table is included in Appendix 1. The dating results show three age groups: 444-443 Ma (Early Silurian), 301-278 Ma (Late Carboniferous-late Early Permian), and 258-250 Ma (latest Late Permian). The significance of these results will be discussed in the corresponding mega-episodes in the following section.

\section{Discussion of a possible geodynamic evolution}

Based on regional unconformities of Early Ediacaran, early Middle Cambrian, Dapingian, Late Pridoli, Early Visean, Late Wuchiapingian and Late Olenekian ages (Figures. 2\&3), litho-biostratigraphy, peak metamorphic ages, peak magmatic ages, and geological relationships, we recognized six Neoproterozoic to Early Triassic tectono-stratigraphic megaepisodes in Indochina and adjacent areas (Figure 12; Tran et al., 2018). 


\subsection{Neoproterozoic-Early Cambrian evolution}

During the Neoproterozoic-Early Cambrian mega-episode, branches of the ProtoTethys, including the Proto-Song Ma Ocean and the Tam Ky-Phuoc Son Ocean, separated the Sino-Vietnam (South China) terrane from the Indochina terranes (Figure 12A). Popular views of the Song Ma oceanic crust suggested a Devonian-Carboniferous age based on ophiolite dating along the Song Ma suture (Nguyen V.V. et al., 2013; Zhang et al., 2014). However, recent evidence suggests that an older Proto-Song Ma Ocean existed during the Neoproterozoic-Early Cambrian, which closed before the Middle Cambrian.

First, the 470 Ma gabbroic intrusion into the chromite-bearing Nui Nua serpentinized complex (Figure 1; Pham et al., 2014) indicates the presence of an oceanic crust older than that documented by Nguyen V.V. et al. (2013).

Second, the Nam Co subduction accretionary complex and the Posen I-type granite (760-750 Ma) is interpreted to record Neoproterozoic northward subduction of a Proto-Tethys branch under the southwestern Sino-Vietnam composite terrane. Detrital zircon U-Pb ages from meta-sandstones are unimodal and yield a major peak centered around $\sim 850 \mathrm{Ma}$, characteristics of a magmatic arc setting (Bui V. H. et al., 2018). The detrital zircon U-Pb age distribution is comparable to that of the southern Yangtze Block, but differs from Indochina or Cathaysia, indicating a primary detrital input derived from the southern Yangtze Block (Bui V. H. et al., 2018).

Third, subduction-related magmatism is also well documented along the SW margin of the Ailaoshan suture zone (Cai et al., 2014) as well as along the northwest margin of the Yangtze Block (Dong et al., 2012).

Fourth and finally, the similar lithology and benthic fauna of Middle Cambrian-Early Ordovician deposits on both side of the Proto-Song Ma suture (see section 5.2) suggest that the 
suturing of the Sino-Vietnam and Viet-Lao terranes occurred in the Early Cambrian or Late Neoproterozoic (Figure 12B). This is coeval with the Pan-African orogenesis, in which many Proterozoic continents amalgamated to form the Gondwana supercontinent (Torsvik and Cocks, 2017).

Since the Early Cambrian, a shallow marine shelf setting existed over the Hoang Lien Son-Ailaoshan terrane and southern Yangtze block resulting in carbonate and phosphate deposition. This setting was located far north of the Proto-Song Ma suture and extends to over the southern Yangtze block. Meanwhile, similar settings also developed in Australia, India, Korea, NW China and Mongolia; and this time period is recognized as one of the greatest phosphogenic episodes in geological history (Cook and Shergold, 2005).

During the same period, north of the Kon Tum terrane, the Tam Ky-Phuoc Son ocean, as documented by $518 \mathrm{Ma}$ and $502 \mathrm{Ma}$ trondhjemite-tonalite suite (Nguyen et al., 2019) extracted from the Kham Duc complex, still separated the Kon Tum terrane from other terranes of Indochina (Figure 12B).

\subsection{Middle Cambrian-Early Ordovician evolution}

During this time, in the Sino-Vietnam composite terrane, shallow shelf carbonate deposition dominated to the NW and a rich benthic trilobite and brachiopod fauna thrived (Chang Pung and Lutxia Fms.) (Figures. 2\&3), similar to the sedimentary cover of the Yangtze Block. Meanwhile, deep-water sediments containing agnostidae cold-water trilobites and graptolite (Than Sa Fm.) formed in the SE along the Jiangnan zone. In addition, the lithological and paleontological characteristics of the North West Vietnam domain are very similar to the North East Vietnam domain and Yunnan (China) (Pham, 2008). The trilobites in the Late Cambrian-Early Ordovician Chang Pung and Ham Rong Fms. in northern Vietnam are also similar to those in the Tarutao Group in south Thailand (Pham, 2008, p. 158; Shergold, 1995; 
Wongwanich and Burrett, 1983). These lines of evidence suggest that in Early Paleozoic times, the Sino-Vietnam composite terrane, Viet-Lao terrane and Viet-Cambodia terrane formed part of a single continent, or were situated closely to each other (Figure 12B; Burrett et al., 2014; Tran and Vu, 2011, pp. 116-118).

To the north and west of the Kon Tum terrane, volcano-terrigenous sediments of the deep-water A Vuong Fm. formed in an island arc setting associated with the northward subduction of the Proto-Tethys under the Viet-Lao/Phu Hoat terrane (Tran, 1979, pp. 56-57., Tran et al 2018), which by then was already amalgamated to the Sino-Vietnam composite terrane (Faure et al., 2018). The subduction might also have been directed southward, as suggested by the Nui Vu and Phong Hanh volcano-plutonic arc complex (Figures. 2, 3 \& 12B) (Gardner et al., 2017; Tran et al., 2014., Tran, 1998; Tran and Vu, 2011, pp. 59-60).

During this time, Indochina and South China were adjacent to Gondwana, sharing the same sediment source (Burrett et al., 1990, 2014; Usuki et al., 2013). North China, South China and the Lhasa block were all in a largely similar faunal province, suggesting their close geographical location in the Middle Cambrian (Torsvik and Cocks, 2017).

\subsection{Middle Ordovician-Silurian evolution}

Tectonically, this mega-episode is characterized by the Early Paleozoic orogeny. In the Sino-Vietnam (South China) composite terrane, the orogeny was an intra-continental one (e.g. Charvet et al., 2010; Faure et al., 2009), which in North East Vietnam resulted in slope to deepwater flysch sedimentation of conglomerate and sandstone interbedded with graptolitic shale. The orogeny initiated along the north and NW margins of the former Cathaysia Block, causing a shallowing upward depositional trend and NW-ward migration of shallow water conditions, while a stable carbonate-dominated shelf still continued to exist over most of the Yangtze Block (Charvet, 2013; Shu et al., 2015; Xu et al., 2016). A similar situation exists in North East 
Vietnam. Meanwhile, in North West Vietnam, shallow marine shelf existed throughout the Late Ordovician-Silurian, which is consistent with this domain being on the southwest margin of the Yangtze Block during the Early Paleozoic, before being laterally displaced by Cenozoic escape tectonics (Faure et al., 2018; Leloup et al., 2001; Tapponnier et al., 1990; Tran and Vu, 2011, pp. 519-523).

In the Indochina composite terrane, possible bivergent subduction of the Tam Ky-Phuoc Son ocean underneath the Kon Tum terrane, Viet-Lao terrane, and Viet-Cambodia terrane (470$450 \mathrm{Ma}$ ) has been suggested (Gardner et al., 2017). This was followed by an Ordovician continental collision (450-425 Ma) that caused high-grade metamorphism and widespread migmatisation in the Kon Tum massif. The northward subduction under the Viet-Lao terrane and Viet-Cambodia terrane (Faure et al., 2018) is indicated by: 1) the Late Ordovician-Early Silurian Long Dai volcano-plutonic arc which includes the Dai Loc S-type granites and felsic volcanic series in Donken, Laos (Gardner et al., 2017; Thassanapak et al., 2018); 2) the volcanosedimentary Long Dai Fm. (Figures. 2\&3) and its equivalence in Laos as well as the Song Ca deep-water sediments, which probably formed in a back-arc basin (Figure 12C). The southward subduction is indicated by the 476-450 Ma I-type calc-alkaline diorite-granite Dien Binh complex (Figure 12C). The relicts of the consumed ocean are preserved as dismembered ophiolites along sutures flanking the Kon Tum terrane such as the Tam Ky-Phuoc Son suture (northern margin), Po Ko suture (western margin), and possibly also the Chu Sinh suture (southern margin). Faure et al. (2018) considered the Kon Tum terrane to be the exposed lower crust of the Viet-Cambodia terrane. However, the presence of the Chu Sinh suture, if recognized, would suggest that the Kon Tum massif might have been a separate terrane.

The metamorphism of the Kham Duc and Nui Vu complexes at 450 Ma (Usuki et al., 2009) as well as U-Pb dates at 468.6 $\pm 1.5 \mathrm{Ma}$ of granulite in the Song Bien area (Roger et al., 2007) signify the complete closure of the Vietnam part of the Tam Ky-Phuoc Son ocean as 
early as the Middle Ordovician. This is accompanied by 444-443 Ma S-type migmatitic granites of the Chu Lai complex in the Kon Tum terrane (sample OG08) and granites from the Viet-Lao terrane (sample DH13) (Figure 11). The closure timing is compatible with the basal conglomerate of the Late Ordovician-Early Silurian Long Dai Fm. Subsequent uplifts are indicated by a number of younger unconformities overlain by conglomerate beds such as the Late Silurian unconformity separating the Long Dai and Dai Giang Fm., the end-Silurian unconformity separating the Dai Giang Fm. and the Tan Lam Fm. in Viet-Lao terrane (Figures. 2\&3), as well as the significant Early Carboniferous unconformity in both Vietnam and Laos (Figure 9). This suggests that the collision between the Kon Tum and Viet-Cambodia terranes with the Viet-Lao terrane might have been diachronous, starting in north Kon Tum and younging northwestward to north Laos and northeast Thailand. The similar timing between these two Early Paleozoic orogenies, being intracontinental in Sino-Vietnam, and collisional in Indochina, led Faure et al. (2018) to argue for the suturing along the Tam Ky-Phuoc Son zone as the driving force for the intra-continental orogeny in South China, instead of a collision between South China and Australia as earlier proposed (Xu et al., 2016).

Following this event, the Indochina and Sino-Vietnam composite terranes might have formed a single landmass since at least the Late Silurian and Devonian. This is supported by the similarity in lithofacies as well as marine shelly fauna and flora fossils (Janvier et al., 1997; Tong et al., 1996). The depositional environment changed from deep-water into shallow marine in NE Vietnam (Kien An Fm.) and in the southern Viet-Lao terrane (Dai Giang Fm.). Meanwhile, a deep marine environment persisted throughout the Late Silurian within northern Viet-Lao terrane (Song Ca Fm. and lower Tay Trang Fm.) (Figures. 2\&3), and at the southwestern margin of Viet-Lao terrane (Thassanapak et al., 2018). Recently, Loydell et al. (2019) interpreted the Early Silurian graptolites found in the Viet-Lao terrane to reflect mid to high latitude, closer to peri-Gondwana Europe and Arabia than South China, which laid in a 
low latitude position. This conclusion was based on the identification of stenothermic species of graptolite, the distribution of which were dominantly controlled by sea surface temperature, which in turn was used to infer their paleolatitude. However, as also noted by Loydell et al. (2019), the disposition of continents could have deflected warm current polewards and cold water equatorwards, thereby increase the latitudinal range of these species. Therefore, the paleolatitude difference between the Sino-Vietnam and Indochina composite terranes might not have been so large.

In addition, Late Ordovician-Early Silurian shelly faunas of South China (SinoVietnam) are closely related to coeval faunas on the Sibumasu composite terranes (Metcalfe, 2013). The Sino-Vietnam-Indochina superterrane may have separated from Gondwana before the Devonian, probably in the Middle-Late Silurian (Burrett et al., 1990; Torsvik and Cocks, 2017; Young and Janvier, 1999).

\subsection{Devonian-Early Carboniferous (Tournaisian) evolution}

During this mega-episode, the tectonic regime was mostly stable. A passive continental shelf developed and marine transgression occurred over most of the study area (Figure 12E), while the western Indochina margin was in an active setting (Qian et al., 2016). The Devonianearliest Carboniferous sequence is floored by a coarse-grained siliciclastic unit deposited unconformably on older rocks. This unit transitions upward into shallow marine carbonates and manganese-bearing siliceous shales. Fauna and flora in the Sino-Vietnam and Indochina composite terranes do not show relationship to those in Gondwana since the Devonian-Early Carboniferous, indicating that these terranes had drifted away from peri-Gondwana by this time (Golonka, 2006; 2012; Metcalfe, 2013). Since the late Middle Devonian, the Song Ma ocean reopened as evidenced by the ultramafic rocks with a Sm-Nd age of $387 \mathrm{Ma}$ (Nguyen V. V. et al., 2013), and zircon U-Pb SHRIMP ages from 340 to $330 \mathrm{Ma}$ (Zhang et al., 2014). Meanwhile, some deep-water deposits are preserved in narrow continental troughs in north Central Vietnam, 
southern Laos, NW Laos and NE Thailand. The Late Devonian chert deposits in Loei were interpreted to have formed in a back-arc basin developed on continental crust, based on the intercalation with mafic volcanic beds, and the presence of shallow marine sandstone and limestone underlying the chert (Udchachon et al., 2015, 2017).

\subsection{Early Carboniferous (Visean)-Middle Permian evolution}

The tectono-stratigraphic evolution of this mega-episode resulted in the establishment of stable carbonate platform in the Sino-Vietnam composite terrane and eastern Indochina, as well as coal bearing deposits in Laos and NE Thailand containing abundant Cathaysia-affinity plant fossils (Laveine et al., 2009; Ueno and Charoentitirat, 2011). During the Early Carboniferous, the Song Ma ocean was still present as a Paleo-Tethys branch that separated the Sino-Vietnam and Indochina composite terranes (Figure 12E\&F), as discussed in the previous section. The Song Ma ocean might have extended into the Bangxi-Chengxing tectonic zone in the middle Hainan Island where oceanic basalt dated $330 \mathrm{Ma}$ by zircon U-Pb exists ( $\mathrm{He}$ et al, 2018). However, this was probably a narrow ocean (Faure et al., 2014; Metcalfe, 2013), due to similarities in the flora and fauna on both side of the Song Ma suture. Meanwhile, detrital zircon $\mathrm{U}-\mathrm{Pb}$ analysis of Permian-Triassic marine sediments in NE Thailand indicates the beginning of arc activity in the Sukhothai Arc during the Late Carboniferous to Early Permian (Hara et al., 2015).

Some authors have suggested the existence of an oceanic crust between north Vietnam and South China, of which remnants are preserved along the so-called Dian Qiong suture. Along this zone, Early Carboniferous-Permian gabbro, pillow basalts, and mafic dykes have been found in in NE Vietnam, Yunnan, and Guangxi Provinces, and were interpreted as the "Babu ophiolites" (Cai and Zhang, 2009; Halpin et al., 2016; Liu et al., 2018; Tran et al., 2007). However, their geological setting, as intrusions within Carboniferous platform carbonates, and 
geochemistry show that they are intraplate basalts corresponding to remote parts of the Emeishan Large Igneous Province (Faure et al., 2014, 2016; Izokh et al., 2005).

Widespread island arc and active margin volcano-plutonic assemblages (300-270 Ma) developed throughout NW Vietnam, Laos, NE Thailand, Cambodia, SW Vietnam, the Gulf of Thailand and East Malaysia, stretching for more than $2000 \mathrm{~km}$ from north to south (Figure 8; Tran et al., 2015, 2018). This is further supported by our new data from the Gulf of Thailand (samples 538333, 538329, 453011, 453014, and 453015) and Cambodia (sample 538736) (Figure 11). Different models have been proposed to explain the distribution of this volcanic belt. The western margin can be explained by eastward subduction of a branch of the PaleoTethys under the Indochina composite terrane (Morley, 2018) or associated back-arc basin development (Qian et al., 2016; Rossignol et al., 2016). In NW Laos, the magmatism was attributed to the subduction under the Viet-Lao terrane of oceanic crust attached to the SinoVietnam composite terrane (Kamvong et al., 2014), possibly referring to the Song Ma oceanic crust. However, we prefer eastward subduction of a branch of the Paleo-Tethys under Indochina as the main driver for the widespread magmatism (Figure 12F), since the Song Ma ocean, as argued above, was too narrow for its subduction to have significant influence.

After being separated from Gondwana since the Middle-Late Silurian, South China and Indochina drifted northward and were in a low latitude position by the Late Carboniferous (Li et al., 2004). Sibumasu was part of Gondwana's Himalaya-Australian margin until the Early Permian (Sakmarian). However, during the late Early Permian, Sibumasu drifted rapidly northward away from Gondwana and entered into warm-climate equatorial Cathaysian faunal province in the Late Permian (Metcalfe, 2013, 2017). 


\subsection{Late Permian-Early Triassic evolution}

This mega-episode was characterized by Late Permian-Early Triassic intra-continental rift systems possibly triggered by the 260-257 Ma Emeishan Large Igneous Province mantle plume event, and resuturing between Indochina and Sino-Vietnam composite terranes. These rift systems were filled by mafic to felsic volcanic complexes with both high-Ti and low-Ti compositions. The rifting reached its climax at $257 \pm 3 \mathrm{Ma}$ (Tran T.H. et al., 2016). Our ca. 258 Ma rhyolites from the Tu Le rift (samples TT01 and TT02) from the North West Vietnam domain, and 256-250 Ma granosyenite and granite (samples CH01, CH02, NS1 and NS2) from the North East Vietnam domain (Figure 11) are consistent with this tectonic setting in the Late Permian. In addition, the 250 Ma gabbro from the Kon Tum terrane (sample OG9, Figure 11) might be due to plume-related magmatism in the Late Permian (Nakano et al., 2013; Osanai et al., 2008; Owada et al., 2016). This mantle heat source may play a key role in the Late PermianEarly Triassic tectonic exhumation and metamorphic core complex formation over the Kon Tum terrane that overprinted the earlier Ordovician metamorphic event (Faure et al 2018).

The rewelding of Indochina and Sino-Vietnam along the Song Ma suture is evidenced by a large Indosinian orogenic belt consisting of widespread anatectic S-type granites (260-248 $\mathrm{Ma}$ ) in the Viet-Lao terrane (Figures. 8 \& 12G), and Late Permian-Early Triassic high to ultrahigh pressure metamorphic rocks of LT eclogite and HP granulite along the Song Ma suture zone (Nakano et al., 2008; Zhang et al., 2014). This event created a single vast landmass as indicated by similar plant remains and faunas found in both the Sino-Vietnam and Indochina composite terranes (Bercovici et al., 2012). In particular, rich Cathaysian flora is found in coalbearing deposits scattered throughout N. Vietnam, NW Laos, E. Thailand, SW Cambodia (see part 3.6 for more details). These deposits and their flora indicate a warm and wet climate, close to the equator. This is consistent with paleomagnetic studies of basalts in the Song Da rift, 
which put NW Vietnam's paleolatitude at $\sim 5^{\circ} \mathrm{N}$ or $5^{\circ} \mathrm{S}$ during the Late Permian (Geissman et al., 2018).

Meanwhile, the Gondwana genus Glossopteris are found in Phetchabun, E. Thailand growing alongside typical Cathaysian species (Rigby, 1998). Mixed flora is also documented along the Paleo-Tethyan margin of Gondwana during this time (Srivastava and Agnihotri, 2010). Furthermore, the discovery of the terrestrial Dicynodon fossil in Luangprabang, NW Laos, whose presence are also known in Laurussia, suggest at least a temporal terrestrial connection between Laurussia and the Sino-Vietnam-Indochina super-terrane during the Late Permian (Bercovici et al., 2012).

On a related note, several authors have attributed the Sam Nua arc (also known as the Song $\mathrm{Ca}$ arc) to the subduction of the Song Ma ocean (eg. Faure et al., 2016; Liu et al., 2012; Shi et al., 2015), which contradicts available geological data. Volcano-sedimentary deposits of the Sam Nua basin is represented by the Dong Trau Fm., resting unconformably on Carboniferous-Middle Permian carbonates. The formation's clastic components contain Anisian ammonoids such as Amphipopanoceras aff. dzeginense, Paradanubites palmatus, $P$. sp., Leiophyllites aff. visendus and Paraceratites sp. (Tran and Vu, 2011). The zircon U-Pb LAICP-MS ages of porphyritic dacite and porphyritic rhyolite are 245-229 Ma (Pham et al., 2015). These lines of evidence place the Dong Trau Fm. firmly in the Anisian (Middle Triassic), which post-dates the Song Ma resuturing event. No Late Permian-Early Triassic deposits are found in the Sam Nua basin. Also, based on the analysis of trace and rare-earth elements, the Dong Trau volcanic suite was probably derived from continental crust associated with the post-collision Sam Nua intra-continental rift.

After the Late Permian-Early Triassic mega-episode, the collision between Sibumasu and Sino-Vietnam-Indochina started from the Late Triassic, and was sometimes referred to as 
the later stage of the Indosinian Orogeny (Fontaine and Workman, 1978; Helmcke, 1984; Sone and Metcalfe, 2008). More recently, the term "Cimmerian Orogeny" in the sense of Sengor (1988) was introduced for this event (Torsvik and Cocks, 2017, Wang et al 2018). However, following the initial pre-Late Triassic definition of the Indosinian orogeny, responsible for the collision between Indochina and Sino-Vietnam (S. China) blocks (Fromaget, 1941), the former term does not seem appropriate since the collision took place after the Late Triassic and involved two different continents, namely the Sibumasu and the Sino-Vietnam-Indochina composite terranes. Consequently, we propose the name Trans-Mekong orogeny for this suturing event, the final stage of which during the Jurassic formed mainland Southeast Asia (Charusiri et al., 2002; Metcalfe, 2013; Sone and Metcalfe, 2008).

\section{Conclusion}

Based on a comprehensive review of available geological data as well as new radiometric dating results, we recognized six major mega-episodes for the tectono-stratigraphic evolution of Indochina and adjacent areas during the Neoproterozoic to Early Triassic:

1) The Neoproterozoic-Early Cambrian mega-episode: Branches of the Proto-Tethys, including the Proto-Song Ma Ocean and the Tam Ky-Phuoc Son Ocean, separated the SinoVietnam (South China) and individual Indochina terranes. The Sino-Vietnam and Viet-Lao terranes then amalgamated during the Neoproterozoic or Early Cambrian.

2) The Middle Cambrian-Early Ordovician mega-episode: Shallow shelf carbonate deposition and the development of rich benthic faunas dominated north of the Proto-Song Ma suture, while in the south a deep marine and volcanic arc setting developed.

3) The Middle Ordovician-Silurian mega-episode: The Tam Ky-Phuoc Son Ocean subducted under the Viet-Lao, Viet-Cambodia and Kon Tum terrane, leading to the collision between these terranes along sutures around the Kon Tum terrane. This collision triggered the 
Early Paleozoic intra-continental orogeny in the Sino-Vietnam composite terrane, and a unified Sino-Vietnam-Indochina super-terrane was established.

4) The Devonian-Tournaisian mega-episode: A passive continental shelf developed and marine transgression occurred over most of the study area, while the western Indochina margin was in an active setting. In some narrow troughs, deep water radiolarian chert were deposited on continental crust.

5) The Early Carboniferous (Visean)-Middle Permian mega-episode: The narrow Song Ma ocean reopened along the Proto-Song Ma suture, while widespread arc magmatism developed in western Indochina due to eastward subduction of the Paleo-Tethys.

6) The Late Permian-Early Triassic mega-episode: The Emeishan mantle plume triggered rifting in north Vietnam, and possibly crustal heating in the Kon Tum terrane in central Vietnam. The Sino-Vietnam and Indochina composite terranes collided again along the Song Ma suture. Contrary to popular beliefs, the "Sam Nua arc" postdates this collision.

The subsequent collision between Sibumasu and Indochina, here termed the TransMekong orogeny, during the Late Triassic-Jurassic formed mainland Southeast Asia.

\section{Acknowledgements}

We are deeply indebted to Prof. Clive Burrett for his detailed and valuable comments and suggestions. We express our gratitude to Prof. Osanai Y. and Assoc. Prof. Nakano N. at the Kyushu University, Japan, and Dr. Tadashi Usuki from Institute of Earth Sciences, Academia Sinica, Taiwan (IESAS) for assisting us on the zircon $\mathrm{U}-\mathrm{Pb}$ radiometric dating of our samples. We sincerely thank the two anonymous reviewers and the JAES editors for providing constructive comments that helped to improve the manuscript. 


\section{References}

Ali, J.R., Thompson, G.M., Zhou, M.-F., Song, X., 2005. Emeishan large igneous province, SW China. Lithos 79, 475-489. https://doi.org/10.1016/j.lithos.2004.09.013

Barber, A.J., Ridd, M.F., Crow, M.J., 2011. The origin, movement and assembly of the preTertiary tectonic units of Thailand, in: Ridd, M.F., Barber, A.J., Crow, M.J. (Eds.), The Geology of Thailand. The Geological Society of London, pp. 507-537. https://doi.org/10.1144/GOTH.19

Barr, S.M., Charusiri, P., 2011. Volcanic rocks, in: Ridd, M.F., Barber, A.J., Crow, M.J. (Eds.), The Geology of Thailand. The Geological Society of London, pp. 415-439. https://doi.org/10.1144/GOTH.15

Bercovici, A., Bourquin, S., Broutin, J., Steyer, J.S., Battail, B., Véran, M., Vacant, R., Khenthavong, B., Vongphamany, S., 2012. Permian continental paleoenvironments in Southeastern Asia: New insights from the Luang Prabang Basin (Laos). J. Asian Earth Sci. 60, 197-211. https://doi.org/10.1016/j.jseaes.2012.08.019

Boonsoong, A., Panjasawatwong, Y., Metparsopsan, K., 2011. Petrochemistry and tectonic setting of mafic volcanic rocks in the Chon Daen-Wang Pong area, Phetchabun, Thailand. Isl. Arc 20, 107-124. https://doi.org/10.1111/j.1440-1738.2010.00748.x

Bui, H.H., Nguyen, V.K., Nguyen, Q.T., Bui, V.D., 2018. Preliminary results on the deep water sedimentary facies of the Late Ordovician-Early Silurian deposits on Co To Archipelago, NE Vietnam, in: ASEAN Geosciences and Earth Resources for Sustainable Development. Presented at the GEOSEA XV, Publish House for Science and Technology, Hanoi, Vietnam, pp. 197-198.

Bui, M.T. (Ed.), 2010. Magmatism in Vietnam. Vietnam Institute of Geosciences and Mineral resources. Publishing House of Cartography, Hanoi, pp.368. In Vietnamese with English summary 
Bui, V.H., Kim, Y., Thanh, N.X., Tran, T.H., Yi, K., 2018. Neoproterozoic deposition and Triassic metamorphism of metasedimentary rocks in the Nam Co Complex, Song Ma Suture Zone, NW Vietnam. Geosci. J. 22, 549-568. https://doi.org/10.1007/s12303018-0026-Z

Bunopas, S., 1994. The regional stratigraphy, paleogeographic and tectonic events of Thailand and continental Southeast Asia, in: Proceedings of the International Symposium on Stratigraphic Correlation of Southeast Asia. Department of Mineral Resources, Bangkok, Thailand, pp. 2-24.

Burrett, C., Long, J., Stait, B., 1990. Early-Middle Palaeozoic biogeography of Asian terranes derived from Gondwana. Geol. Soc. Lond. Mem. 12, 163-174. https://doi.org/10.1144/GSL.MEM.1990.012.01.14

Burrett, C., Udchachon, M., Thassanapak, H., 2016. Palaeozoic correlations and the palaeogeography of the Sibumasu (Shan-Thai) Terrane: a brief review. Res. Knowl. 2, 1-17. https://doi.org/10.14456/randk.2016.12

Burrett, C., Khin Zaw, Meffre, S., Lai, C.K., Khositanont, S., Chaodumrong, P., Udchachon, M., Ekins, S., Halpin, J., 2014. The configuration of Greater Gondwana-Evidence from LA ICPMS, U-Pb geochronology of detrital zircons from the Palaeozoic and Mesozoic of Southeast Asia and China. Gondwana Res. 26, 31-51. https://doi.org/10.1016/j.gr.2013.05.020

Cai, J.-X., Zhang, K.-J., 2009. A new model for the Indochina and South China collision during the Late Permian to the Middle Triassic. Tectonophysics 467, 35-43. https://doi.org/10/ddgdbr

Cai, Y., Wang, Y., Cawood, P.A., Fan, W., Liu, H., Xing, X., Zhang, Y., 2014. Neoproterozoic subduction along the Ailaoshan zone, South China: Geochronological and geochemical 
evidence from amphibolite. Precambrian Res. 245, 13-28. https://doi.org/10.1016/j.precamres.2014.01.009

Carter, A., Roques, D., Bristow, C., Kinny, P., 2001. Understanding Mesozoic accretion in Southeast Asia: Significance of Triassic thermotectonism (Indosinian orogeny) in Vietnam. Geology 29, 211. https://doi.org/10.1130/00917613(2001)029<0211:UMAISA > 2.0.CO;2

Charusiri, P., Daorerk, V., Archibald, D., Hisada, K., Ampaiwan, T., 2002. Geotectonic evolution of Thailand: A new synthesis. J. Geol. Soc. Thail. 1, 1-20.

Charvet, J., 2013. The Neoproterozoic-Early Paleozoic tectonic evolution of the South China Block: An overview. J. Asian Earth Sci. 74, 198-209. https://doi.org/10.1016/j.jseaes.2013.02.015

Charvet, J., Shu, L., Faure, M., Choulet, F., Wang, B., Lu, H., Breton, N.L., 2010. Structural development of the Lower Paleozoic belt of South China: Genesis of an intracontinental orogen. J. Asian Earth Sci. 39, 309-330. https://doi.org/10.1016/j.jseaes.2010.03.006

China Geological Survey, 2004. Geological Map of the People's Republic of China Explanatory Notes.

Cocks, L.R.M., Torsvik, T.H., 2013. The dynamic evolution of the Palaeozoic geography of $\begin{array}{llll}\text { eastern } & \text { Asia. } & \text { Earth-Sci. } & \text { Rev. }\end{array}$ https://doi.org/10.1016/j.earscirev.2012.12.001

Cook, P.J., Shergold, J.H., 2005. Phosphate deposits of the world. Cambridge University Press, pp.408.

Dang, M.C., 2013. Lithological characteristics of the turbiditic Co To Formation and its geodynamics significance. Vietnam Institute of Geosciences and Mineral Resources, Hanoi, pp.101. In Vietnamese. 
Dao, D.T., Huynh, T. (Eds.), 1995. Magmatic formations, Geology of Vietnam. Geological Survey of Vietnam., Hanoi, pp.360. In Vietnamese.

Department of Mineral Resources, 2014. Geology of Thailand. Department of Geology and Mineral Resources, Ministry of Natural Resources and Environment, Bangkok, Thailand, pp.508.

Dinh, S.Q., 2017. Petrographic characteristics and zircon U-Pb geochronology of granitogneiss rocks in the Chu Lai-Kham Duc area (Quang Nam province). Sci. Technol. Dev. J.-Nat. Sci. 1, 258-272. https://doi.org/10.32508/stdjns.v1i6.636. In Vietnamese with English abstract.

Doan N.T., Ta H.P., 2003. Some new data on the Upper Devonian sediments in Van Yen (Son La). Vietnam Journal of Earth Sciences, 25/3, 269-274.

Dong, Y., Liu, X., Santosh, M., Chen, Q., Zhang, X., Li, W., He, D., Zhang, G., 2012. Neoproterozoic accretionary tectonics along the northwestern margin of the Yangtze Block, China: Constraints from zircon $\mathrm{U}-\mathrm{Pb}$ geochronology and geochemistry. Precambrian Res. 196-197, 247-274. https://doi.org/10.1016/j.precamres.2011.12.007

Dovjikov, A.E. (Ed.), 1965. Explanatory note to the Geological map of North Vietnam at scale 1:500.000. General Department of Geology, Hanoi, pp.669. In Russian.

Duong, X.H. (Ed.), 1980. Characteristics fossils in the North Vietnam. Publish House for Science and Technology, Hanoi, pp.600. In Vietnamese.

Faure, M., Lepvrier, C., Van Nguyen, V., Van Vu, T., Lin, W., Chen, Z., 2014. The South China Block-Indochina collision: where, when, and how? J. Asian Earth Sci. 79, 260-274.

Faure, M., Lin, W., Chu, Y., Lepvrier, C., 2016. Triassic tectonics of the southern margin of the South China Block. Comptes Rendus Geosci. 348, 5-14. https://doi.org/10.1016/j.crte.2015.06.012 
Faure, M., Nguyen, V.V., Hoai, L.T.T., Lepvrier, C., 2018. Early Paleozoic or Early-Middle Triassic collision between the South China and Indochina Blocks: The controversy resolved? Structural insights from the Kon Tum massif (Central Vietnam). J. Asian Earth Sci. 166, 162-180. https://doi.org/10.1016/j.jseaes.2018.07.015

Faure, M., Shu, L., Wang, B., Charvet, J., Choulet, F., Monie, P., 2009. Intracontinental subduction: a possible mechanism for the Early Palaeozoic Orogen of SE China. Terra Nova 21, 360-368. https://doi.org/10.1111/j.1365-3121.2009.00888.x

Findlay, R.H.H., Trinh, P.T., 1997. The Structural Setting of the Song Ma Region, Vietnam and the Indochina-South China Plate Boundary Problem. Gondwana Res. 1, 11-33. https://doi.org/10.1016/S1342-937X(05)70003-4

Fontaine, H., Workman, D.R., 1978. Review of the geology and mineral resources of Kampuchea, Laos and Vietnam, in: Nutalaya, P. (Ed.), Proceedings of the Third Regional Conference on Geology and Mineral Resources of Southeast Asia. Bangkok, Thailand, pp. 539-603.

Fromaget, J., 1952. Etudes géologiques sur le Nord-Ouest du Tonkin et le Nord du Haut Laos (2e et 3e parties), Bulletin du Service Géologique de l'Indochine XXIX.

Fromaget, J., 1941. L'Indochine française, sa structure géologique, ses roches, ses mines et leurs relations possibles avec la tectonique, Bulletin du Service Géologique de l'Indochine. Hanoi, pp.140.

Fyhn, M.B.W., Cuong, T.D., Hoang, B.H., Hovikoski, J., Olivarius, M., Tuan, N.Q., Tung, N.T., Huyen, N.T., Cuong, T.X., Nytoft, H.P., Abatzis, I., Nielsen, L.H., 2018. Linking Paleogene rifting and inversion in the northern Song Hong and Beibuwan basins, Vietnam, with left-lateral motion on the Ailao Shan-Red River Shear Zone. Tectonics. https://doi.org/10/gdvjk8 
Fyhn, M.B.W., Green, P.F., Bergman, S.C., Van Itterbeeck, J., Tri, T.V., Dien, P.T., Abatzis, I., Thomsen, T.B., Chea, S., Pedersen, S.A.S., Mai, L.C., Tuan, H.A., Nielsen, L.H., 2016. Cenozoic deformation and exhumation of the Kampot Fold Belt and implications for south Indochina tectonics. J. Geophys. Res. Solid Earth 121, 5278-5307. https://doi.org/10.1002/2016JB012847

Fyhn, M.B.W., Thomsen, T.B., Keulen, N., Knudsen, C., Rizzi, M., Bojesen-Koefoed, J., Olivarius, M., Tri, T.V., Phach, P.V., Minh, Nielsen, L.H., 2019. Detrital zircon ages and heavy mineral composition along the Gulf of Tonkin - Implication for the provenance of reservoir sand in the Yinggehai-Song Hong Basin. Mar. Pet. Geol. 101, 162-179. https://doi.org/10.1016/j.marpetgeo.2018.11.051

Gardner, C.J., Graham, I.T., Belousova, E., Booth, G.W., Greig, A., 2017. Evidence for Ordovician subduction-related magmatism in the Truong Son terrane, SE Laos: Implications for Gondwana evolution and porphyry $\mathrm{Cu}$ exploration potential in SE Asia. Gondwana Res. 44, 139-156. https://doi.org/10.1016/j.gr.2016.11.003

Gatinsky, Y.G., Hutchison, C.S., 1986. Cathaysia, Gondwanaland, and the Paleotethys in the evolution of continental Southeast Asia. Presented at the GEOSEA V, Geological Society of Malaysia, pp. 179-199.

Gatinsky, Y.G., Tran, V.T., Isaev, E.N., Le, V.C., Kamenetsky, A., Kujenui, N., Raskazov, IU., Sukhov, V., 1970. On the tectonic zoning in North Vietnam. J. Geol. 1-41.

Geissman, J.W., Cung, T.C., Borgfeldt, T., 2018. Paleomagnetic, rock magnetic, and anisotrophy of magnetic susceptibility data from Upper Permian and Lower Triassic volcanic sequences from Northwest Vietnam and their bearing on the accretion history of Southeast Asia. Presented at the GEOSEA XV, Publish House for Science and Technology, Hanoi, pp. 128-130. 
Golonka, J., 2006. Global plate tectonics and paleogeography of Southeast Asia. Faculty of Geology, Geophysics and Environmental Protection. AGH University of Science and Technology, Kraków.

Golonka Jan, 2012. Paleozoic paleoenvironment and paleolithofacies maps of Godwana. AGH University of Science and Technology Press. https://doi.org/10.13140/2.1.3481.4403

Gonez, P., Nguyen, H.H., Ta, H.P., Clément, G., Janvier, P., 2012. The oldest flora of the South China Block, and the stratigraphic bearings of the plant remains from the Ngoc Vung Series, northern Vietnam. J. Asian Earth Sci. 43, 51-63. https://doi.org/10.1016/j.jseaes.2011.08.007

Gubler, J., 1935. Estudes gesologiques au Cambodge occidental. Bull. Serv. Géol. Indochine, pp.176.

Ha, X.B., Vuong, V.D., Nguyen, V.L., Bui, Q.T., Khampha, P., Phouphet, C., 2009. Geological and Mineral resources map of Southern Laos at scale 1:500,000 - Final report for evaluation of bauxite and other deposits of Southern Laos. Laos PDR Department of Geology and Mines and INTERGEO, Vietnam Geology and Mineral Resources Department, Hanoi. In Vietnamese.

Hada, S., 1999. Rift-drift history and the amalgamation of Shan-Thai and Indochina/East Malaya blocks. Gondwana Dispers. Asian Accretion-IGCP 321 Final Results Vol. 6787.

Halpin, J.A., Tran, H.T., Lai, C.-K., Meffre, S., Crawford, A.J., Khin Zaw, 2016. U-Pb zircon geochronology and geochemistry from NE Vietnam: A 'tectonically disputed' territory between the Indochina and South China blocks. Gondwana Res. 34, 254-273. https://doi.org/10.1016/j.gr.2015.04.005

Hara, H., Kunii, M., Hisada, K., Kamata, Y., Ueno, K., Kon, Y., Assavapatchara, S., Treerotchananon, A., Charoentitirat, T., Charusiri, P., 2015. Provenance and detrital 
zircon U-Pb ages from Permo-Triassic marine sediments in Northern Thailand: records of the Sukhothai Arc evolution and the Paleo-Tethys subduction. Presented at the 4th symposium of the International Geosciences Programme (IGCP), Chulalongkorn University, Bangkok, Thailand, pp. 20-23.

He, H., Wang, Y., Qian, X., Zhang, Y., 2018. The Bangxi-Chenxing tectonic zone in Hainan Island (South China) as the eastern extension of the Song Ma-Ailaoshan zone: Evidence of late Paleozoic and Triassic igneous rocks. J. Asian Earth Sci. 164, 274-291.

Helmcke, D., 1984. The orogenic evolution (Permian-triassic) of central Thailand. Implications on paleogeographic models for mainland SE-Asia. Mémoire de la Société Géologique de France 147, 83-91.

Hoang, N., Flower, M., 1998. Petrogenesis of Cenozoic Basalts from Vietnam: Implication for Origins of a "Diffuse Igneous Province." J. Petrol. 39, 369-395. https://doi.org/10.1093/petroj/39.3.369

Hoffet, J.-H., 1933. Étude géologique sur le centre de l'Indochine entre Tourane et le Mékong (Annam central et Bas-Laos), par Josué-Heilmann Hoffet. impr. Protat frères, pp.154.

Hutchison, C.S., 2007. Geological Evolution of South-East Asia. Geological Society of Malaysia, pp.433.

Hutchison, C.S., 1989. The Palaeo-Tethyan Realm and Indosinian Orogenic System of Southeast Asia, in: Şengör, A.M.C. (Ed.), Tectonic Evolution of the Tethyan Region, NATO ASI Series. Springer Netherlands, Dordrecht, pp. 585-643. https://doi.org/10.1007/978-94-009-2253-2_25

Izokh, A., Polyakov, G., Hoa, T.T., Balykin, P., Phuong, N.T., 2005. Permian-Triassic ultramafic-mafic magmatism of northern Vietnam and southern China as expression of plume magmatism. Russ. Geol. Geophys. Geol. Geofiz. 46, 922-932. 
Izokh, A.E., Tran, T.H., Ngo, T.P., Tran, Q.H., 2006. Ophiolite ultramafic-mafic associations in the northern structure of the Kon Tum block (central Vietnam). J. Geol. 20-26.

Jacob, C., 1921. Études geologiques dans le Nord-Annam et le Tonkin, Bulletin du Service geologique de 1'Indochine X fasc 1. Imprimerie d'Extrême-Orient.

Janvier, P., Racheboeuf, P., Huu, H.N., Nhat, T.D., 2003. Devonian fish (Placodermi, Antiarcha) from Tra Ban Island (Bai Tu Long Bay, Quang Ninh Province, Vietnam) and the question of the age of the Do^ Son Formation. J. Asian Earth Sci. 7.

Janvier, P., Thanh, T.D., Phuong, T.H., Truong, D.N., 1997. The Devonian vertebrates (Placodermi, Sarcopterygii) from Central Vietnam and their bearing on the Devonian palaeogeography of Southeast Asia. J. Asian Earth Sci. 15, 393-406. https://doi.org/10.1016/S0743-9547(97)00020-2

Kamvong, T., Khin Zaw, Meffre, S., Maas, R., Stein, H., Lai, C.K., 2014. Adakites in the Truong Son and Loei fold belts, Thailand and Laos: Genesis and implications for geodynamics and metallogeny. Gondwana Res. 26, 165-184. https://doi.org/10.1016/j.gr.2013.06.011

Khin Zaw, Meffre, S., Lai, C.-K., Burrett, C., Santosh, M., Graham, I., Manaka, T., Salam, A., Kamvong, T., Cromie, P., 2014. Tectonics and metallogeny of mainland Southeast Asia - A review and contribution. Gondwana Res. 26, 5-30. https://doi.org/10.1016/j.gr.2013.10.010

Kun, S.C., Say, T.S., 1986. Apercu sur la Geologie es les Resources Minerales du Kampuchea. Presented at the First Conference on the Geology of Indochina, Ho Chi Minh City, Vietnam, pp. 533-534.

Laveine, J.-P., Ratanasthien, B., Sitirach, S., Demarque, D., 2009. The Carboniferous flora of northeastern Thailand: Additional documentation from the Na Duang-Na Klang basin. Rev. Paleobiologie 28, 315-331. 
Le, D.B., Bui, M.T., 2008. History of tectono-magmatic evolution in Vietnam. Vietnam J. Earth Sci. 388-395. In Vietnamese.

Leloup, P.H., Arnaud, N., Lacassin, R., Kienast, J.R., Harrison, T.M., Trong, T.T.P., Replumaz, A., Tapponnier, P., 2001. New constraints on the structure, thermochronology, and timing of the Ailao Shan-Red River shear zone, SE Asia. J. Geophys. Res. Solid Earth 106, 6683-6732. https://doi.org/10.1029/2000JB900322

Leloup, P.H., Tapponnier, P., Lacassin, R., Searle, M.P., 2007. Discussion on the role of the Red River shear zone, Yunnan and Vietnam, in the continental extrusion of SE Asia Journal, Vol. 163, 2006, 1025-1036. J. Geol. Soc. 164, 1253-1260. https://doi.org/10.1144/0016-76492007-065

Lepvrier, C., Faure, M., Van, V.N., Vu, T.V., Lin, W., Trong, T.T., Hoa, P.T., 2011. Northdirected Triassic nappes in Northeastern Vietnam (East Bac Bo). J. Asian Earth Sci. 41, 56-68. https://doi.org/10/dkt3q5

Lepvrier, C., Maluski, H., Van Tich, V., Leyreloup, A., Truong Thi, P., Van Vuong, N., 2004. The Early Triassic Indosinian orogeny in Vietnam (Truong Son Belt and Kontum Massif); implications for the geodynamic evolution of Indochina. Tectonophysics, Asthenosphere-Lithosphere Dynamic Responses to Tethyan Plate Collisions 393, 87118. https://doi.org/10.1016/j.tecto.2004.07.030

Lepvrier, C., Van Vuong, N., Maluski, H., Truong Thi, P., Van Vu, T., 2008. Indosinian tectonics in Vietnam. Comptes Rendus-Geosci. 340, 94-111. https://doi.org/10.1016/j.crte.2007.10.005

Li, P., Rui, G., Junwen, C., Ye, G., 2004. Paleomagnetic analysis of eastern Tibet: implications for the collisional and amalgamation history of the Three Rivers Region, SW China. J. Asian Earth Sci. 24, 291-310. https://doi.org/10.1016/j.jseaes.2003.12.003 
Liu, H., Peng, T., Guo, X., 2018. Geochronological and geochemical constraints on the coexistent N-MORB- and SSZ-type ophiolites in Babu area (SW China) and tectonic implications. J. Geol. Soc. 175, 667-678. https://doi.org/10.1144/jgs2017-121

Liu, J., Tran, M.-D.D., Tang, Y., Nguyen, Q.-L.L., Tran, T.-H.H., Wu, W., Chen, J., Zhang, Z., Zhao, Z., 2012. Permo-Triassic granitoids in the northern part of the Truong Son belt, NW Vietnam: Geochronology, geochemistry and tectonic implications. Gondwana Res. 22, 628-644. https://doi.org/10.1016/j.gr.2011.10.011

Liu, Y.P., Ye, L., Li, C.Y., Song, B., Li, T.S., Guo, L.G., Pi, D.H., 2006. Discovery of the Neoproterozoic magmatics in southeastern Yunnan: Evidence from SHRIMP zircon U$\mathrm{Pb}$ dating and lithogeochemistry. Acta Petrol. Sin. 22, 916-926.

Long, J.A., Burrett, C.F., Ngan, P.K., Janvier, P., 1990. A new bothriolepid antiarch (Pisces, Placodermi) from the Devonian of Do Son peninsula, northern Vietnam. Alcheringa Australas. J. Palaeontol. 14, 181-194. https://doi.org/10.1080/03115519008619054

Loydell, D.K., Udchachon, M., Burrett, C., 2019. Llandovery (lower Silurian) graptolites from the Sepon Mine, Truong Son Terrane, central Laos and their palaeogeographical significance. J. Asian Earth Sci. 170, 360-374. https://doi.org/10.1016/j.jseaes.2018.11.013

Ludwig, K., 2008. User's Manual for Isoplot 3.70 (Berkeley Geochronology Center Special Publication No. 4). Berkeley Geochronology Center.

Maluski, H., Lepvrier, C., Leyreloup, A., Tich, V.V., Thi, P.T., 2005. 40Ar-39Ar geochronology of the charnockites and granulites of the Kan Nack complex, Kon Tum Massif, Vietnam. J. Asian Earth Sci. 25, 653-677. https://doi.org/10.1016/j.jseaes.2004.07.004

Manaka, T., Khin Zaw, Meffre, S., Vasconcelos, P.M., Golding, S.D., 2014. The Ban Houayxai epithermal $\mathrm{Au}-\mathrm{Ag}$ deposit in the Northern Lao PDR: Mineralization related to the Early 
Permian arc magmatism of the Truong Son Fold Belt. Gondwana Res. 26, 185-197. https://doi.org/10.1016/j.gr.2013.08.024

Metcalfe, I., 2017. Tectonic evolution of Sundaland. Bulletin of the Geological Society of Malaysia 63, 27-60

Metcalfe, I., 2013. Gondwana dispersion and Asian accretion: Tectonic and palaeogeographic evolution of eastern Tethys. J. Asian Earth Sci. 66, 1-33. https://doi.org/10.1016/j.jseaes.2012.12.020

Minezaki, T., Hisada, K., Hara, H., Kamata, Y., 2019. Tectono-stratigraphy of Late Carboniferous to Triassic successions of the Khorat Plateau Basin, Indochina Block, northeastern Thailand: Initiation of the Indosinian Orogeny by collision of the Indochina and South China blocks. J. Asian Earth Sci. 170, 208-224. https://doi.org/10.1016/j.jseaes.2018.10.020

Morley, C.K., 2018. Understanding Sibumasu in the context of ribbon continents. Gondwana Res. 64, 184-215. https://doi.org/10.1016/j.gr.2018.07.006

Nagy, E.A., Maluski, H., Lepvrier, C., Schärer, U., Thi, P.T., Leyreloup, A., Thich, V.V., 2001. Geodynamic Significance of the Kontum Massif in Central Vietnam: Composite 40Ar/39Ar and U - Pb Ages from Paleozoic to Triassic. J. Geol. 109, 755-770. https://doi.org/10.1086/323193

Nakano, N., Osanai, Y., Minh, N.T., Miyamoto, T., Hayasaka, Y., Owada, M., 2008. Discovery of high-pressure granulite-facies metamorphism in northern Vietnam: Constraints on the Permo-Triassic Indochinese continental collision tectonics. Comptes Rendus Geosci. 340, 127-138. https://doi.org/10.1016/j.crte.2007.10.013

Nakano, N., Osanai, Y., Owada, M., Nam, T.N., Charusiri, P., Khamphavong, K., 2013. Tectonic evolution of high-grade metamorphic terranes in central Vietnam: Constraints 
from large-scale monazite geochronology. J. Asian Earth Sci. 73, 520-539. https://doi.org/10.1016/j.jseaes.2013.05.010

Nakano, N., Osanai, Y., Owada, M., Nam, T.N., Toyoshima, T., Binh, P., Tsunogae, T., Kagami, H., 2007. Geologic and metamorphic evolution of the basement complexes in the Kontum Massif, central Vietnam. Gondwana Res. 12, 438-453.

Nghiem, N.M., 2018. Overview on Paleophyta and Mesophyta in Vietnam and adjacent areas. Presented at the GEOSEA XV, Publish House of Science and Technology, Hanoi, pp. $34-37$.

Ngo, X.T., Nguyen, T.B.T., 2016. Tectonic nature of the meta-mafic rocks of Huoi Hao Formation in Chieng Khuong, Son La. J. Geol, Ser. A, 356, 3-4, 19-29. In Vietnamese Nguyen, B.M., Ta, H.P., Doan, N.T., 2013. On the Carboniferous-Permian carbonate sediments in the Mường Lống area, Kỳ Sơn District, Nghệ An. J. Geol. In Vietnamese.

Nguyen, C.D., Duong, H.S., Bui, D.C., Bui, M.T., 2015. U-Pb zircon SHRIMP isotopic age of Nam Giai granitoid in Phu Hoat (Nghe An) and their geodynamic significance., in: Geology and Mineral Resources, 50th Anniversary of Vietnam Institute of Geosciences and Mineral Resources. Vietnam Institute of Geosciences and Mineral Resources, pp. 34-39. In Vietnamese.

Nguyen, C.H., 1984. A new collection of Late Permian flora discovered in the Yen Duyet Formation at Xom Trao, Ky Son, Ha Son Binh. Vietnam J. Earth Sci. 72-79. In Vietnamese.

Nguyen, H.H., Nguyen, D.H., Nguyen, D.K., 1998. New data on Upper Silurian and EifelGivetian sediments in the Thanh Son -Thanh Thuy map sheet. J. Geol. 54-55. In Vietnamese. 
Nguyen, M.Q., Vu, A.D., Le, M.H., 2016. Upper Devonian-Lower Carboniferous microfossils from cherts in Truong Son Fold Belt, Central Vietnam: Geological framework implications. J. Geol. Ser. A 68-77. In Vietnamese.

Nguyen, N.H. (Ed.) 1996. Geological and Mineral resources map of Nam Bo Plain sheet series at scale 1:200,000 -. Geological survey of Vietnam, Hanoi.

Nguyen, Q.M., Feng, Q., Zi, J.-W., Zhao, T., Tran, H.T., Ngo, T.X., Tran, D.M., Nguyen, H.Q., 2019. Cambrian intra-oceanic arc trondhjemite and tonalite in the Tam Ky-Phuoc Son Suture Zone, central Vietnam: Implications for the early Paleozoic assembly of the Indochina Block. Gondwana Res. https://doi.org/10.1016/j.gr.2019.01.002

Nguyen, T.B.T., Quach, D.T., Ho, T.T., Tran, D.D., Nguyen, D.C., Bui, T.A., Nguyen, T.X., Dang, V.L., Vu, M.H., 2018. U-Pb zircon age of Dien Binh granitoid pluton in Bo Y, Ngoc Hoi, Kon Tum province and its implications. Presented at the GEOSEA XV, Publish House of Science and Technology, Hanoi, p. 328.

Nguyen, T.G., Tran, T.H., 2016. Multiple magma intrusions along the margin of Nong Son Mesozoic basin, central Viet Nam and its regional significance. J. Geol. 37-49. In Vietnamese.

Nguyen, V.L. (Ed.), 1985. Upper Paleozoic in Vietnam. Publish House for Science and Technology, Hanoi, pp.532. In Vietnamese.

Nguyen, V.N., Hoang, Q.C., Ha, X.B., Le, D.N., Nguyen, T.B.T., Dao, D.T., 2005. U-Pb zircon age of granitoids of the Huoi Tong complex. Presented at the Commemorative conference of 60 years of Vietnam Geology, Department of Geology and Mineral resources of Vietnam, Hanoi, pp. 164-170. In Vietnamese.

Nguyen, V.P., 2000. The biostratigraphic zonation of Silurian graptolites in Vietnam. J. Geol. 10-18. In Vietnamese. 
Nguyen, V.T., 1998. Geological and mineral resource map of the M'Drak sheet series, scale 1:50,000. The Department of Geology and Minerals of Vietnam. Hanoi.

Nguyen, V.T., 1996. Geological and Mineral resources map of the Hue-Quang Ngai sheet series at scale 1:200,000. The Department of Geology and Minerals of Vietnam. Hanoi.

Nguyen, V.V., Hansen, B., Wemmer, K., Ta, T.T., Mai, H.C., 2005. Sm/Nd isochronous age of ultramafic rocks within the Song Hong shear zone and its geodynamic implications. J. Earth Sci. 97-102.

Nguyen, V.V., Hansen, B.T., Wemmer, K., Lepvrier, C., Vu, V.T., Ta, T.T., 2013. U/Pb and $\mathrm{Sm} / \mathrm{Nd}$ dating on ophiolitic rocks of the Song Ma suture zone (northern Vietnam): Evidence for upper paleozoic paleotethyan lithospheric remnants. J. Geodyn. 69, 140147. https://doi.org/10.1016/j.jog.2012.04.003

Nguyen, X.B., Duong, V.C., Trinh, V.L., 2015. Tectonic zones of continental southern Viet Nam. J. Geol.-Ser. A 11-27. In Vietnamese.

Nguyen, X.K., 2000. Some new results of study on sedimentary formations in the Co To archipelago (Quang Ninh province). Geol. Miner. Resour. - Inst. Geol. Miner. Resour. 55-60. In Vietnamese.

Nguyen, X.T., Tran, V.T., 1992. Geological formation and geodynamics of Vietnam. Geological Survey of Vietnam., Hanoi, pp.274. In Vietnamese.

Osanai, Y., 2004. Metamorphic evolution of high-pressure and ultrahigh-temperature granulites from the Kontum Massif, central Vietnam. Gondwana Res. 7, 1360-1363.

Osanai, Y., Nakano, N., Owada, M., Nam, T.N., Miyamoto, T., Minh, N.T., Nam, N.V., Tri, T.V., 2008. Collision zone metamorphism in Vietnam and adjacent South-eastern Asia: Proposition for Trans Vietnam Orogenic Belt. J. Mineral. Petrol. Sci. 103, 226-241. https://doi.org/10.2465/jmps.080620e 
Owada, M., Osanai, Y., Hokada, T., Nakano, N., 2006. Timing of metamorphism and formation of garnet granite in the Kontum Massif, central Vietnam: Evidence from monazite EMP dating. J. Mineral. Petrol. Sci. 101, 324-328. https://doi.org/10.2465/jmps.060617a

Owada, M., Osanai, Y., Nakano, N., Adachi, T., Kitano, I., Tri, T.V., Kagami, H., 2016. Late Permian plume-related magmatism and tectonothermal events in the Kontum Massif, central Vietnam. J. Mineral. Petrol. Sci. 111, 181-195. https://doi.org/10.2465/jmps.151019b

Pham, D.L., Dang, M.C., Pham, N.D., Bui, T.A., Cao, T.T.B., Le, D.C., Luu, V.T., Bui, T.V., Phung, X.Q., 2015. Petrological characteristics of volcanic formation in Dong Trau Formation, North Vietnam. Geol. Miner. Resour. 8-14. In Vietnamese.

Pham, H.L., Ta, T.T.H., 2003. Tectonic evolution history of Vietnam and adjacent areas. Geol. Resour. Environ. South Vietnam - South Vietnam Mapp. Div. 17-22. In Vietnamese.

Pham, K.N. (Ed.), 2008. The Cambrian system in Vietnam. The Science and Technology Publishing House, pp.216. In Vietnamese with English summary.

Pham, T.H., Nguyen, T.D., Nguyen, T.B.T., Nguyen, T.M., Pham, M., 2016. U-Pb ages and Hf isotopic composition of zircon and bulk rock geochemistry of the Dai Loc granitoid complex in Kontum massif: Implications for early Paleozoic crustal evolution in Central Vietnam. J. Mineral. Petrol. Sci. 111, 326-336. https://doi.org/10.2465/jmps.151229

Pham, T.H., Son, L.M., Dung, L.T., Thanh, N.X., 2014. 470 Ma aged gabbro-diabase in Nui Nua area of Song Ma structure zone. J. Geol. Ser. A 1-10. In Vietnamese.

Phan, C.T., Nguyen, N.L., Le, Q.H., 2009. Geological map of Cambodia, Laos and Vietnam at scale 1:1,500,00. Vietnam Institute of Geosciences and Mineral Resources.

Phan, T.T., 1995. Indosinia geoblock in the Indosinian tectonic movement in Indochina. J. Geol. 317-318. In Vietnamese. 
Phan, V.Q., Hoang, H.H., 2008. Tectonic structure and geodynamic features of the Song Hong basin. Petrovietnam J. 26-33.

Polyakov, G.V., Nguyen, T.Y., Tran, T.H., Ngo, T.P., Izokh, A.E., Balykin, P.A., Glotov, A.I., Tran, Q.H., Hoang, H.T., Bui, A.N., Tran, T.A., 2004. Ultramafic-mafic igenous formations of North Vietnam (Review on the study of Institute of Geology, SB RAS and Institute of Geological Sciences, NCNST of SRV, 1983-2003). J. Geol.-Ser. B 311.

Pusharovsky, IU., 1965. Some opinions on the tectonics of North Vietnam. Geotectonica. In Russian.

Qian, X., Feng, Q., Wang, Y., Chonglakmani, C., Monjai, D., 2016. Geochronological and geochemical constraints on the mafic rocks along the Luang Prabang zone: Carboniferous back-arc setting in northwest Laos. Lithos 245, 60-75. https://doi.org/10.1016/j.lithos.2015.07.019

Rattanasathien, B., 2011. Coal Deposits. in: Ridd, M.F., Barber, A.J., Crow, M.J. (Eds.), The Geology of Thailand. The Geological Society, London, pp. 393-414.

Ren, J., Niu, B., Wang, J., Jin, X., Zhao, L., Liu, R., 2013. Advances in research of Asian geology_A summary of 1:5M International Geological Map of Asia project. J. Asian Earth Sci., Geological Evolution of Asia 72, 3-11. https://doi.org/10.1016/j.jseaes.2013.02.006

Ridd, M.F., Barber, A.J., Crow, M.J. (Eds.), 2011. The geology of Thailand. The Geological Society, London: Williston, VT, pp.626.

Rigby, J.F., 1998. Upper Palaeozoic floras of SE Asia, in: Biogeography and Geological Evolution of SE Asia. Backhuys Publishers, pp. 73-82.

Rizzi, M., Fyhn, M.B.W., Schovsbo, N.H., Korte, C., Hovikoski, J., Olivarius, M., Thomsen, T.B., Keulen, N., Thuy, N.T.T., Hoang, B.H., Dung, B.V., Toan, D.M., Abatzis, I., 
Nielsen, L.H., 2020. Hinterland setting and composition of an Oligocene deep rift-lake sequence, Gulf of Tonkin, Vietnam: Implications for petroleum source rock deposition. Mar. Pet. Geol. 111, 496-509. https://doi.org/10.1016/j.marpetgeo.2019.08.022

Roger, F., Leloup, P.H., Jolivet, M., Lacassin, R., Trinh, P.T., Brunel, M., Seward, D., 2000. Long and complex thermal history of the Song Chay metamorphic dome (Northern Vietnam) by multi-system geochronology. Tectonophysics 321, 449-466. https://doi.org/10.1016/S0040-1951(00)00085-8

Roger, F., Maluski, H., Leyreloup, A., Lepvrier, C., Truong Thi, P., 2007. U-Pb dating of high temperature metamorphic episodes in the Kon Tum Massif (Vietnam). J. Asian Earth Sci. 30, 565-572. https://doi.org/10.1016/j.jseaes.2007.01.005

Rossignol, C., Bourquin, S., Poujol, M., Hallot, E., Dabard, M.-P., Nalpas, T., 2016. The volcaniclastic series from the Luang Prabang Basin, Laos: A witness of a triassic magmatic arc? J. Asian Earth Sci. 120, 159-183. https://doi.org/10.1016/j.jseaes.2016.02.001

Rushton, A., Williams, M., Phong, N.D., Komatsu, T., Siveter, D., Zalasiewicz, J., Tien, D.C., Hien, N.V., Manh, N.H., Tanaka, G., 2018. Early Ordovician (Tremadocian and Floian) graptolites from the Than Sa Formation, northeast Vietnam. Geol. Mag. 155, 14421448. https://doi.org/10.1017/S0016756817000310

Salam, A., Khin Zaw, Meffre, S., McPhie, J., Lai, C.-K., 2014. Geochemistry and geochronology of the Chatree epithermal gold-silver deposit: Implications for the tectonic setting of the Loei Fold Belt, central Thailand. Gondwana Res. 26, 198-217. https://doi.org/10.1016/j.gr.2013.10.008

Saurin, E., 1956. Indochine, in: Lexique Stratigraphique International, III/6a. Centre National de la Recherche Scientifique, Paris. 
Saurin, E., 1935. Études géologiques sur l’Indochine du sud-est (Sud-Annam, Cochinchine, Cambodge oriental), Indo-China, French. Service géologique. Bulletin, vol. xxii, fasc. 1. Hanoi.

Şengör, A.M.C., Altıner, D., Cin, A., Ustaömer, T., Hsü, K.J., 1988. Origin and assembly of the Tethyside orogenic collage at the expense of Gondwana Land. Geol. Soc. Lond. Spec. Publ. 37, 119-181. https://doi.org/10.1144/GSL.SP.1988.037.01.09

Shellnutt, J.G., Denyszyn, S.W., Mundil, R., 2012. Precise age determination of mafic and felsic intrusive rocks from the Permian Emeishan large igneous province (SW China). Gondwana Res. 22, 118-126. https://doi.org/10.1016/j.gr.2011.10.009

Shergold, S.H., 1995. Correlation of the Cambrian biostratigraphy of Northern and Central Australia with that of Southern and Eastern Asia. J. Geol. 48-61.

Shi, M.-F., Lin, F.-C., Fan, W.-Y., Deng, Q., Cong, F., Tran, M.-D., Zhu, H.-P., Wang, H., 2015. Zircon $\mathrm{U}-\mathrm{Pb}$ ages and geochemistry of granitoids in the Truong Son terrane, Vietnam: Tectonic and metallogenic implications. J. Asian Earth Sci. 101, 101-120. https://doi.org/10.1016/j.jseaes.2015.02.001

Shu, L., Wang, B., Cawood, P.A., Santosh, M., Xu, Z., 2015. Early Paleozoic and Early Mesozoic intraplate tectonic and magmatic events in the Cathaysia Block, South China: Two tectonic events in South China. Tectonics 34, 1600-1621. https://doi.org/10.1002/2015TC003835

Sone, M., Metcalfe, I., 2008. Parallel Tethyan sutures in mainland Southeast Asia: New insights for Palaeo-Tethys closure and implications for the Indosinian orogeny. Comptes Rendus - Geosci. 340, 166-179. https://doi.org/10.1016/j.crte.2007.09.008

Sone, M., Metcalfe, I., Chaodumrong, P., 2012. The Chanthaburi terrane of southeastern Thailand: Stratigraphic confirmation as a disrupted segment of the Sukhothai Arc. J. Asian Earth Sci. 61, 16-32. https://doi.org/10.1016/j.jseaes.2012.08.021 
Srivastava, A.K., Agnihotri, D., 2010. Dilemma of late Palaeozoic mixed floras in Gondwana.

$\begin{array}{llll}\text { Palaeogeogr. } & \text { Palaeoclimatol. } & \text { 5alaeoecol. }\end{array}$ https://doi.org/10.1016/j.palaeo.2010.05.028

Ta, H.P., 1998. Upper Devonian Conodont biostratigraphy in Vietnam. J. Geol.-Ser. B 76-84.

Ta, H.P., Le, V.M., 1996. New data on the stratotype of Bo Hieng Formation. J. Geol. 28-33. In Vietnamese.

Tapponnier, P., Lacassin, R., Leloup, P.H., Schärer, U., Dalai, Z., Haiwei, W., Xiaohan, L., Shaocheng, J., Lianshang, Z., Jiayou, Z., 1990. The Ailao Shan/Red River metamorphic belt: Tertiary left-lateral shear between Indochina and South China. Nature 343, 431437. https://doi.org/10.1038/343431a0

Thassanapak, H., Udchachon, M., Burrett, C., 2018. Silurian radiolarians from the Sepon Mine, Truong Son Terrane, central Laos and their palaeogeographic and tectonic significance. Geol. Mag. 155, 1621-1640. https://doi.org/10.1017/S0016756817000425

Thassanapak, H., Udchachon, M., Burrett, C., Feng, Q., 2017. Geochemistry of radiolarian cherts from a Late Devonian continental margin basin, Loei fold belt, Indo-China terrane. J. Earth Sci. 28, 29-50. https://doi.org/10.1007/s12583-017-0738-4

Tong, D.T., Janvier, P., Ta, H.P., 1996. Fish suggests continental connections between the Indochina and South China blocks in Middle Devonian time. Geology 24, 571. https://doi.org/10/fv3gw8

Tong, D.T., Ta, H.P., Janvier, P., Nguyen, H.H., Nguyen, T.T.C., Nguyen, T.D., 2013. Silurian and Devonian in Vietnam-Stratigraphy and facies. J. Geodyn. 69, 165-185. https://doi.org/10.1016/j.jog.2011.10.001

Tong, D.T., Vu, K., 2011. Stratigraphic units of Vietnam, 2nd ed. Vietnam National University Publisher, Hanoi, pp.556. 
Torsvik, T.H., Cocks, L.R.M., 2017. Earth history and palaeogeography. Cambridge University Press, pp.317.

Tran, D.L., Nguyen, X.B., 1988. Geological map of Vietnam at scale 1:500,000. General Department of Mines and Geology.

Tran, N.N., 2003. $750 \mathrm{Ma}$ U-Pb zircon age of the Po Sen Complex and tectonic implication. J. Geol. 11-16. In Vietnamese.

Tran, N.N., Toriumi, M., Sano, Y., Terada, K., Ta, T.T., 2003. 2.9, 2.36, and 1.96 Ga zircons in orthogneiss south of the Red River shear zone in Viet Nam: evidence from SHRIMP $\mathrm{U}-\mathrm{Pb}$ dating and tectonothermal implications. J. Asian Earth Sci. 21, 743-753. https://doi.org/10.1016/S1367-9120(02)00089-5

Tran, Q.H., Bui, A.N., Pham, T.D., Hoang, V.H., 2004. Some material composition characteristics of the mafic-ultramafic intrusions in Central Viet Nam, Central Highlands and North Viet Nam. J. Geol. 116-127. In Vietnamese.

Tran, T. (Ed.), 1998. Geological and Mineral resources map of the Kon Tum - Buon Ma Thuat sheet series at scale 1:200,000. Department of Geology and Mineral resources of Vietnam, Hanoi.

Tran, T.A., Tran, T.H., Nguyen, V.Y., 2005. Geochemical features of Carboniferous-Permian intermediate volcanic formations in South Vietnam. J. Geol. 18-27. In Vietnamese.

Tran, T.H., Dang, V.B., Do, D.T., 2007. The existence of pillow basalts in Cao Bang-Lang Son area and its implications for the structure of Northeast Vietnam. J. Geol. 10-24. In Vietnamese.

Tran, T.H., Izokh, A.E., Polyakov, G.V., Borisenko, A.S., Tran, T.A., Balykin, P.A., Phuong, N.T., Rudnev, S.N., Van, V.V., Nien, B.A., 2008. Permo-Triassic magmatism and metallogeny of Northern Vietnam in relation to the Emeishan plume. Russian Geology and Geophysics 49, 480-491. https://doi.org/10/fnf6rj 
Tran, T.H., Nguyen, V.N., 2006. Tectonic position of intrusive complexes near the Muong Lay Town, Dien Bien province. J. Min. Earth Sci. 43-45. In Vietnamese.

Tran, T.-H., Polyakov, G.V., Tran, T.-A., Borisenko, A.S., Izokh, A.E., Balykin, P.A., Ngo, T.P., Pham, T.-D., 2016. Intraplate Magmatism and Metallogeny of North Vietnam, Modern Approaches in Solid Earth Sciences. Springer International Publishing.

Tran, T.H., Khin Zaw, Halpin, J. a., Manaka, T., Meffre, S., Lai, C.K., Lee, Y., Le, H.V., Dinh, S., 2014. The Tam Ky-Phuoc Son Shear Zone in central Vietnam: Tectonic and metallogenic implications. Gondwana Res. https://doi.org/10.1016/j.gr.2013.04.008

Tran, V.B., 2000. Mineral resource prospecting and geological mapping of the middle Central Laos at the scale 1:200,000. Department of Geology and Mines, Vientiane.

Tran, V.T. (Ed.), 1977. Geology of Vietnam: Northern part. Sciences and Technics Publishing House, Hanoi, pp.355. In Vietnamese.

Tran, V.T. (Ed.), 1979. Geology of Vietnam (North part). General Department of Geology, Hanoi, pp.80.

Tran, V.T., Do, C.D., Dang, Q.L., Quach, D.T., Nguyen, V.H., 2016. Coal-forming episodes in Vietnam, Cambodia and Laos PDR. Presented at the 5th Symposium of the International Geosciences Programme (IGCP) 589, Myanmar Earthquake Committee, Hlaing University, Yangon, Myanmar, pp. 50-53.

Tran, V.T., Faure, M., Nguyen, V.V., Lepvrier, C., Charusiri, P., 2018. Paleozoic tectonostratigraphic evolution of the Indochina and adjacent areas, in: ASEAN Geosciences and Earth Resources for Sustainable Development. Presented at the 15th Regional congress on geology, mineral and energy resources of Southeast Asia (GEOSEA XV), Publish House for Science and Technology, Hanoi, pp. 124-127.

Tran, V.T., Ngo, T.S., Phung, K.K., Nguyen, Q.T., Vu, M.T., 2015. Permian regional geology in Western Indochina, implications for paleotethys active margin of SE-Asia. Presented 
at the 4th Symposium of the International Geosciences Programme (IGCP) 589, Chulalongkorn University, Bangkok, Thailand, pp. 81-82.

Tran, V.T., Vu, K. (Eds.), 2011. Geology and Earth Resources of Vietnam, 2011th ed. Vietnam Public House for Science and Technology, Hanoi, pp.646.

Udchachon, M., Thassanapak, H., Burrett, C., 2017. Palaeoenvironment and palaeogeography of Middle and Upper Devonian strata from the Loei fold belt, Indochina terrane (northeast Thailand). Palaeobiodiversity Palaeoenvironments 97, 497-516. https://doi.org/10.1007/s12549-017-0294-z

Udchachon, M., Thassanapak, H., Feng, Q., Burrett, C., 2015. Palaeoenvironmental implications of geochemistry and radiolarians from Upper Devonian chert/shale sequences of the Truong Son fold belt, Laos: Geochemistry of Late Devonian Chert/Shale Sequences from Laos. Geol. J. 52, 154-173. https://doi.org/10.1002/gj.2743

Ueno, K., Charoentitirat, T., 2011. Carboniferous and Permian, in: Ridd, M.F., Barber, A.J., Crow, M.J. (Eds.), The Geology of Thailand. The Geological Society, London, pp. 71136.

Ueno, K., Miyahigashi, A., Kamata, Y., Kato, M., Charoentitirat, T., Limruk, S., 2012. Geotectonic implications of Permian and Triassic carbonate successions in the Central Plain of Thailand. J. Asian Earth Sci., Geological Anatomy of East and South Asia 61, 33-50. https://doi.org/10.1016/j.jseaes.2012.04.015

United Nations, 1993. Cambodia, Atlast of Mineral Resources of the ESCAP Region. New York.

United Nations, 1990. Lao People's Democratic Republic, Atlast of Mineral Resources of the ESCAP Region. New York. 
Usuki, T., Lan, C.Y., Wang, K.L., Chiu, H.Y., 2013. Linking the Indochina block and Gondwana during the Early Paleozoic: Evidence from U-Pb ages and Hf isotopes of $\begin{array}{llll}\text { detrital } & \text { zircons. } & \text { Tectonophysics } & \text { 586, }\end{array}$ https://doi.org/10.1016/j.tecto.2012.11.010

Usuki, T., Lan, C.-Y., Yui, T.-F., Iizuka, Y., Van Vu, T., Tran, T.A., Okamoto, K., Wooden, J.L., Liou, J.G., 2009. Early Paleozoic medium-pressure metamorphism in central Vietnam: evidence from SHRIMP U-Pb zircon ages. Geosci. J. 13, 245. https://doi.org/10.1007/s12303-009-0024-2

Vu, K., Dao, D.T., Le, D.B., Tong, D.T., Tran, T.T., Tran, V.T., Trinh, D., 2000. Lexicon of geological units of Viet Nam. Publish House for Science and Technology, Hanoi, pp.430.

Vu, V.T., Leyreloup, A., Maluski, H., Lepvrier, C., Lo, C., Nguyen, V.V., 2013. Metamorphic evolution of pelitic-semipelitic granulites in the Kon Tum massif (south-central Vietnam). J. Geodyn., SI : Geodynamics of Vietnam 69, 148-164. https://doi.org/10.1016/j.jog.2012.03.013

Wakita, K., Metcalfe, I., 2005. Ocean Plate Stratigraphy in East and Southeast Asia. J. Asian Earth Sci., Papers presented at the Fourth Annual General Meeting of IGCP Project No. 411 held in Phitsanulok, Thailand, 17-25 November 2002 24, 679-702. https://doi.org/10.1016/j.jseaes.2004.04.004

Wang, P.-L., Lo, C.-H., Lan, C.-Y., Chung, S.-L., Lee, T.-Y., Nam, T.N., Sano, Y., 2011. Thermochronology of the PoSen complex, northern Vietnam: Implications for tectonic evolution in SE Asia. J. Asian Earth Sci. 40, 1044-1055. https://doi.org/10.1016/j.jseaes.2010.11.006

Wang, Q., Deng, J., Li, C., Li, G., Yu, L., Qiao, L., 2014. The boundary between the Simao and Yangtze blocks and their locations in Gondwana and Rodinia: Constraints from detrital 
and inherited zircons. Gondwana Res. 26, 438-448. https://doi.org/10.1016/j.gr.2013.10.002

Wang, Y., Qian, X., Cawood, P.A., Liu, H., Feng, Q., Zhao, G., Zhang, Y., He, H., Zhang, P., 2018. Closure of the East Paleotethyan Ocean and amalgamation of the Eastern Cimmerian and Southeast Asia continental fragments. Earth-Science Reviews, Reconstruction of East Asian Continental Blocks in Pangea 186, 195-230. https://doi.org/10.1016/j.earscirev.2017.09.013

Wongwanich, T., Burrett, C., 1983. The Lower Paleozoic of Thailand. J. Geol. Soc. Thail. 2129.

Xu, Y.-J., Cawood, P.A., Du, Y.-S., 2016. Intraplate orogenesis in response to Gondwana assembly: Kwangsian orogeny, South China. Am. J. Sci. 316, 329-362.

Yan, D.P., Zhou, M.F., Wang, C.Y., Xia, B., 2006. Structural and geochronological constraints on the tectonic evolution of the Dulong-Song Chay tectonic dome in Yunnan province, SW China. J. Asian Earth Sci. 28, 332-353. https://doi.org/10.1016/j.jseaes.2005.10.011

Yan, C., Shu, L., Faure, M., Chen, Y., Huang, R., 2019. Time constraints on the closure of the Paleo-South China Ocean and the Neoproterozoic assembly of the Yangtze and Cathaysia blocks: Insight from new detrital zircon analyses. Gondwana Research 73, 175-189.

Yoshida, K., Sugawara, M., Hada, S., 2002. A preliminary study of the provenance change of Middle-Upper Paleozoic clastic rocks in the Truong Son region, Central Vietnam., in: Geodynamics Processess of Gondwana. Presented at the IGCP Project 411, Phitsanulok, pp. 26-29.

Young, G., Janvier, P., 1999. Early-middle Palaeozoic vertebrate faunas in relation to Gondwana dispersion and Asian accretion. In: Metcalfe, I., Ren, J.S., Charvet, J., 
(Eds.)., Gondwanna Dispersion and Asian Accretion. A.A. Balkema, Rotterdam, 115140.

Zhang, R.Y., Lo, C.-H., Chung, S.-L., Grove, M., Omori, S., Iizuka, Y., Liou, J.G., Tri, T.V., 2013. Origin and Tectonic Implication of Ophiolite and Eclogite in the Song Ma Suture Zone between the South China and Indochina Blocks. J. Metamorph. Geol. 31, 49-62. https://doi.org/10.1111/jmg.12012

Zhang, R.Y., Lo, C.-H., Li, X.-H., Chung, S.-L., Anh, T.T., Tri, T.V., 2014. U-Pb dating and tectonic implication of ophiolite and metabasite from the Song Ma suture zone, northern Vietnam. Am. J. Sci. 314, 649-678. https://doi.org/10.2475/02.2014.07

Zhang, X., Wang, Y., Clift, P.D., Yan, Y., Zhang, Y., Zhang, L., 2018. Paleozoic Tectonic Setting and Paleogeographic Evolution of the Qin-Fang Region, Southern South China Block: Detrital Zircon U-Pb Geochronological and Hf Isotopic Constraints. Geochem. Geophys. Geosystems 19, 3962-3979. https://doi.org/10.1029/2018GC007713 
Figure and Table captions

Figure 1. Paleozoic terrane map of Indochina and adjacent areas. Squared numbers indicate back arc suture: 1) Jinghong suture; 2) Nan-Uttaradit suture; 3) Loei suture; 4) Sra Kaeo suture. Circled numbers indicate metamorphic terranes: 1) Hoang Lien Son-Ailaoshan; 2) Phu Hoat; 3) Dian Cang; 4) Pailin. Numbers in ovals indicate massifs and complexes: 1) Nui Nua massif; 2) Nam Co complex; 3) Huoi Tong massif. Suture zones: ASSZ = Ailaoshan suture zone; BRSZ $=$ Bentong-Raub suture zone; $\mathrm{CRL}=$ Chiang Rai Line; $\mathrm{CMSZ}=$ Changning-Menglian suture zone; CSSZ = Chu Sinh suture zone; PKSZ = Po Ko suture zone; SCSZ = Song Chay suture zone; SMSZ = Song Ma suture zone; TKPSSZ = Tam Ky-Phuoc Son suture zone. Faults: DBF $=$ Dien Bien Phu Fault; MPF: Mae Ping Fault; SCF = Song Ca Fault; TDF = Thakhek-Da Nang Fault. Based on Tran and Vu (2011), Ren et al. (2013), Shu et al. (2014), Burrett et al. (2014), Rossignol et al. (2016), Metcalfe (2017), Faure et al. (2018).

Figure 2. Regional tectono-stratigraphic correlation of Indochina and the surround areas.

Figure 3. Stratigraphic correlation for the Neoproterozoic-Early Devonian in Vietnam. Modified from Tran and $\mathrm{Vu}(2011)$.

Figure 4. Cambrian rocks in North East Vietnam. A) Northwest-dipping monoclinal strata of medium-bedded marmorized limestone interbedded with meta-andesite of the Ha Giang Fm (ع2); $10 \mathrm{~km} \mathrm{SSW} \mathrm{to} \mathrm{Bac} \mathrm{Ha} \mathrm{area,} \mathrm{Lao} \mathrm{Cai} \mathrm{Prov.} \mathrm{B)} \mathrm{Monoclinal} \mathrm{strata} \mathrm{dipping} 230 \angle 45$ of medium-bedded limestone-dolomite rhythmically interbedded with marlaceous shale containing Late Cambrian trilobites of the Chang Pung Formation.

Figure 5. Cambrian brachiopods and trilobites. 1. Billingsella tonkiniana Mansuy, external molds, Ha Giang, Chang Pung Fm, Late Cambrian, Geological Museum, Ha Noi; 2. Calvinella walcotti (Mansuy), Ha Giang, Chang Pung Fm, Late Cambrian, collection of Tran Huu Dan; 3. Annamitia spinifera (Mansuy), Penkai area, Yunnan, Ha Giang Fm, Middle Cambrian, 
collection of Deprat J., 1915; 4. Charchaqia norini Troedsson, Ban Chau area, Thai Nguyen Prov., Than Sa Fm, Late Cambrian, collection of Pham Kim Ngan; 5. Hedinaspis regalis Troedsson, Ban Gioc area, Trung Khanh, Cao Bang Prov., Than Sa Fm, Late Cambrian, collection of Pham Dinh Long; 6. Damesella brevicaudata Walcott, cephalon, Ha Giang Fm, Middle Cambrian, collection of Deprat J. 1915, Geological Museum, Ha Noi.

Figure 6. Examples of Late Ordovician-Early Silurian rocks in Indochina and the surrounding areas. A-C: Turbiditic deposits of the Co To Formation, NE Vietnam; D-F: Basal conglomerate of the Long Dai Formation, SW of Quang Binh Province, near Laos border. (A) Silt and shale interbedded with rippled fine-grained sandstone. (B) Cross-bedded sand with overlying slump deposits. (C) Small scale intra-formational fold and thrust, possibly related to slumping processes. (D), (E), (F): Middle Ordovician basal conglomerates yielding angular, semi-angular and semi-rounded boulders, pebbles and gravels.

Figure 7. Devonian-Carboniferous outcrops in Vietnam. (A) Cross-bedded sandstone and siltstone of the Do Son Group, Hai Phong City. (B) Stratigraphic boundary between Carboniferous and Devonian in the Pho Han Formation, South Cat Ba Island.

Figure 8. Distribution map of Carboniferous-Middle Permian and Late Permian-Triassic rocks. Exposed rocks are based on Ren et al. (2013), while subcrops are based on Booth and Sattayarak (2011) and Minezaki et al. (2019). Numbered basins: 1) Nanpanjiang basin; 2) Song Hien basin; 3) An Chau-Shiwandashan basin; 4) Tu Le basin; 5) Song Da basin; 6) Sam Nua basin; 7) Song Bung-An Khe basin.

Figure 9. Stratigraphic column of the study area for the Latest Devonian-Early Triassic. See Fig. 2 for legends.

Figure 10. Distributive features of chondrite-normalized REE and PM-normalized rare-trace elements of Early Permian igneous rocks (Tran T. A. et al., 2005). A, B: effusives of the Dak 
Lin Formation. C, D: effusives of the Chu Prong Formation. E, F: I-type granitoids of the Ben Giang-Que Son complex.

Figure 11. New zircon U-Pb LA-ICP-MS dating results for Paleozoic rocks in Indochina and adjacent areas.

Figure 12. Sketches of the Neoproterozoic to Early Triassic tectono-stratigraphic and geodynamic evolution of the study area. Prefixes of radiometric ages indicate rock types and affinities: $\gamma$ : granite, $v$ : mafic-ultramafic; I: I-type, S: S-type. SCS = Song Chay Suture; SMS = Song Ma Suture; TK-PS = Tam Ky-Phuoc Son.

Table 1: Location, GPS, lithology, analyzing lab and age dating results for 16 samples in Indochina and adjacent areas. 
Graphical abstract
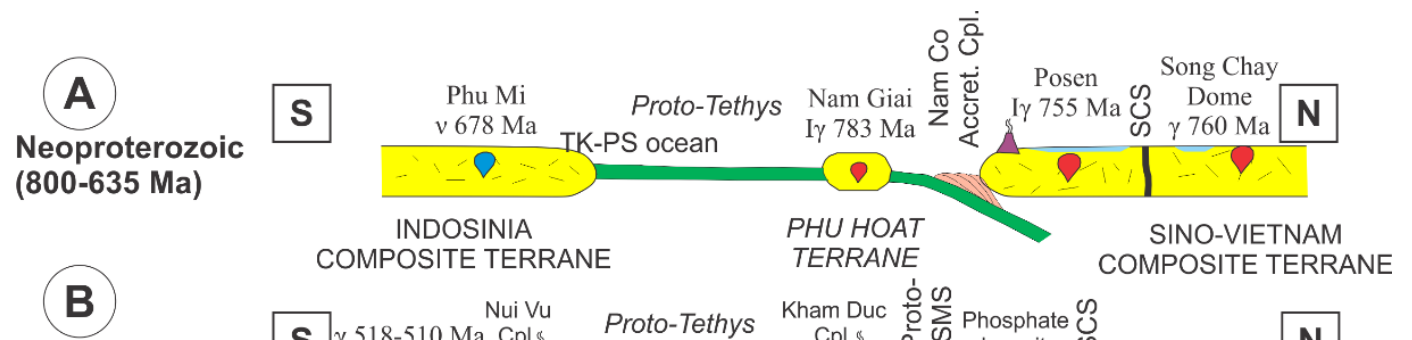

Late NP.-

Early Cambrian

(600-510 Ma)

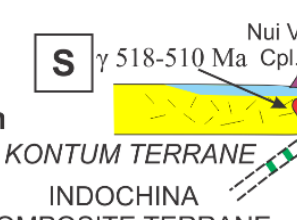

$\mathbf{N}$ COMPOSITE TERRANE
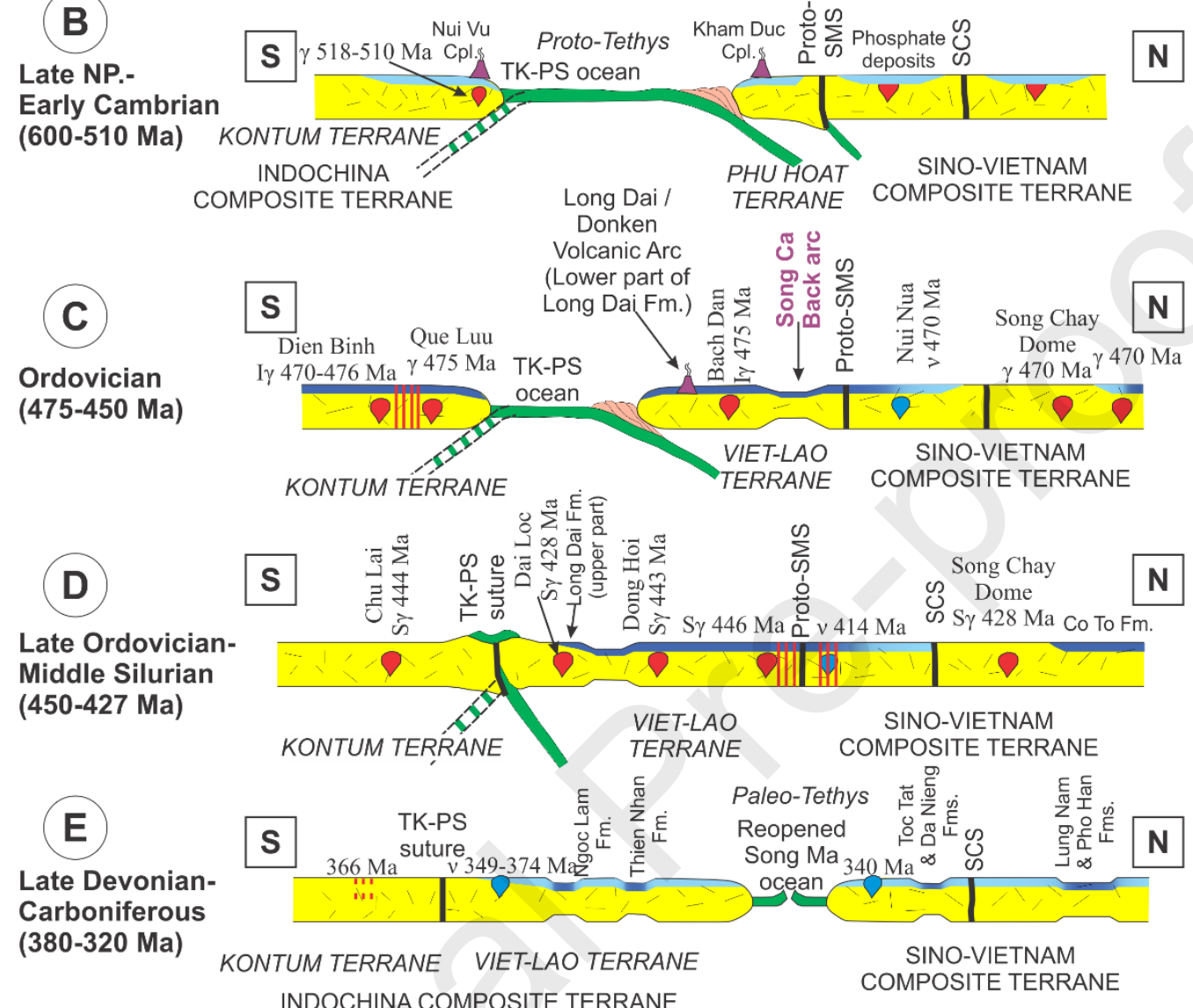

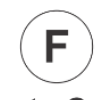

Late Carbon.Middle Permian (310-265 Ma)

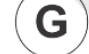

\section{Late Permian- Early Triassic (265-247 Ma)}

\section{Legends \\ Felsic intrusion \\ Deep marine}

INDOCHINA COMPOSITE TERRANE

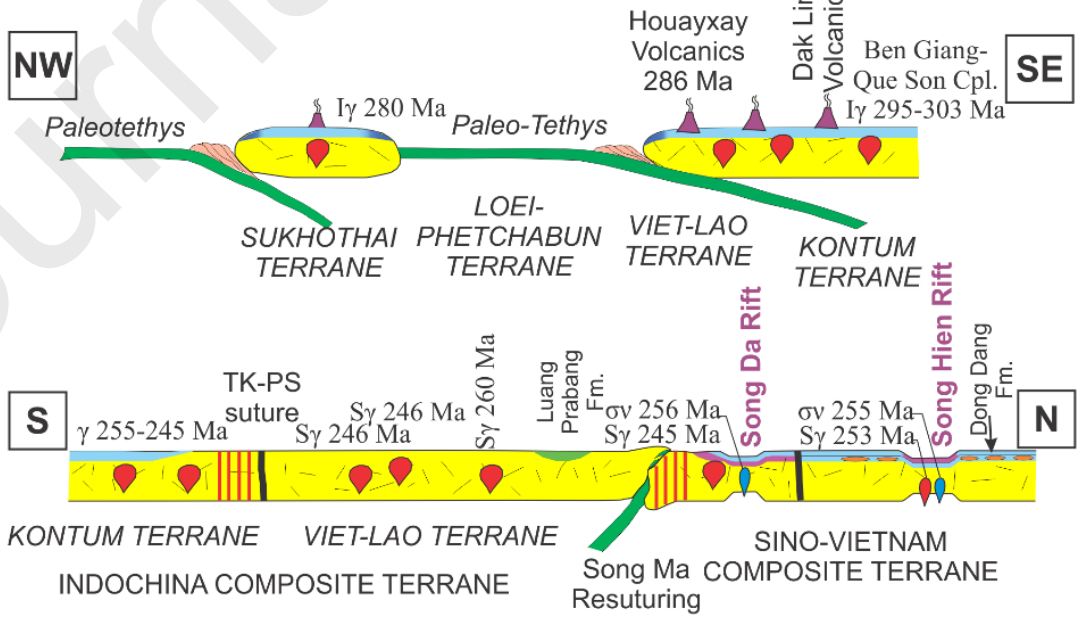

Mafic-Untra Mafic ||||| High-Ultra high intrusion $\quad$ metamorphsim

$$
\text { Shallow marine } \square \begin{aligned}
& \text { Volcano- } \\
& \text { siliciclastics }
\end{aligned}
$$
oceanic crust

- Bauxite
Possible subducting 


\section{Highlights}

Neoproterozoic-Early Cambrian Proto-Song Ma suturing precedes Devonian-Carboniferous reopening

Middle Ordovician-Silurian collision formed a single Sino-Vietnam-Indochina landmass

Paleotethys subduction under Indochina caused Carboniferous-Middle Permian magmatism

Indosinian resuturing along the Song Ma zone was coeval with plume-related rifting 


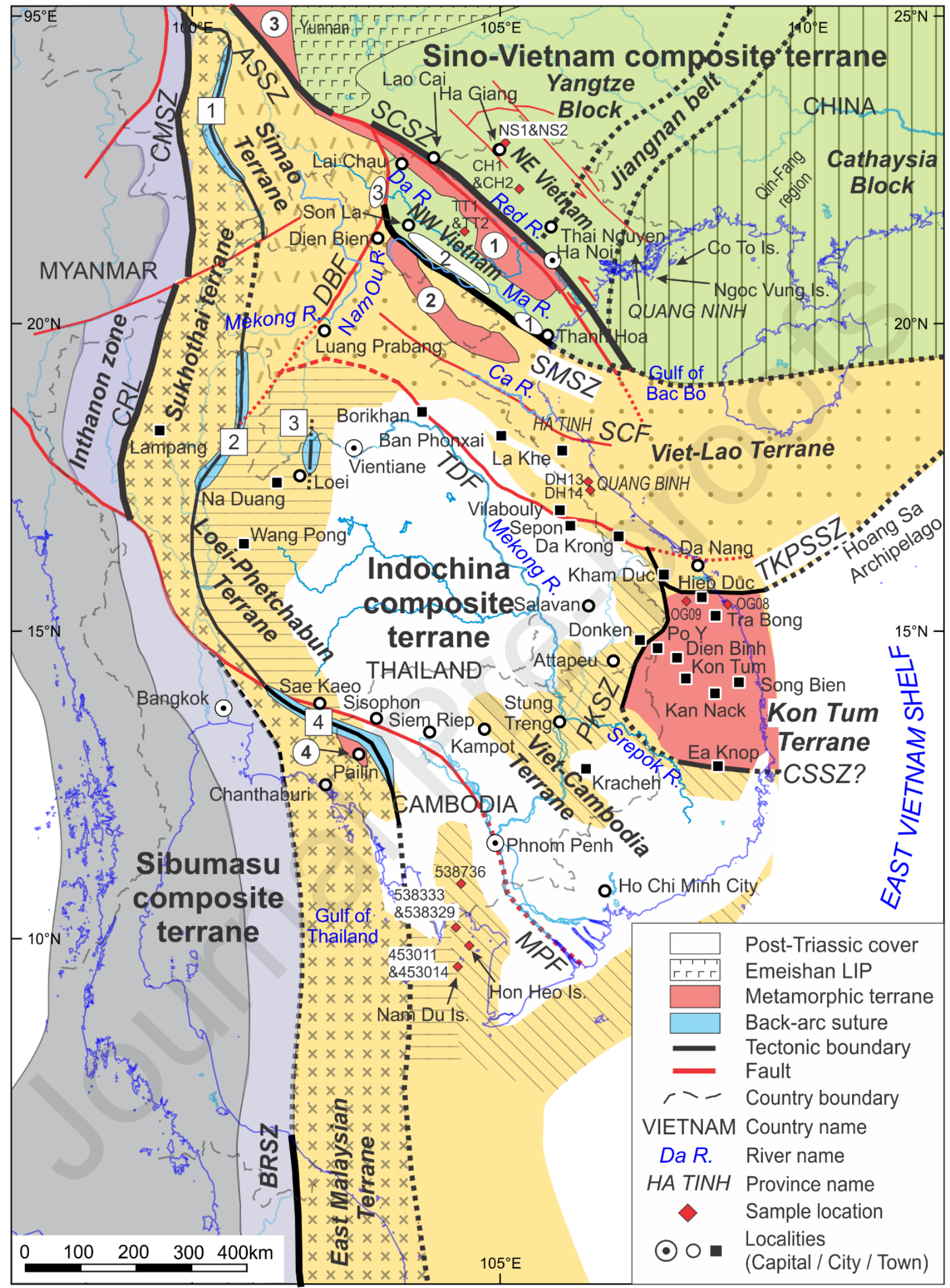


Journal Pre-proofs

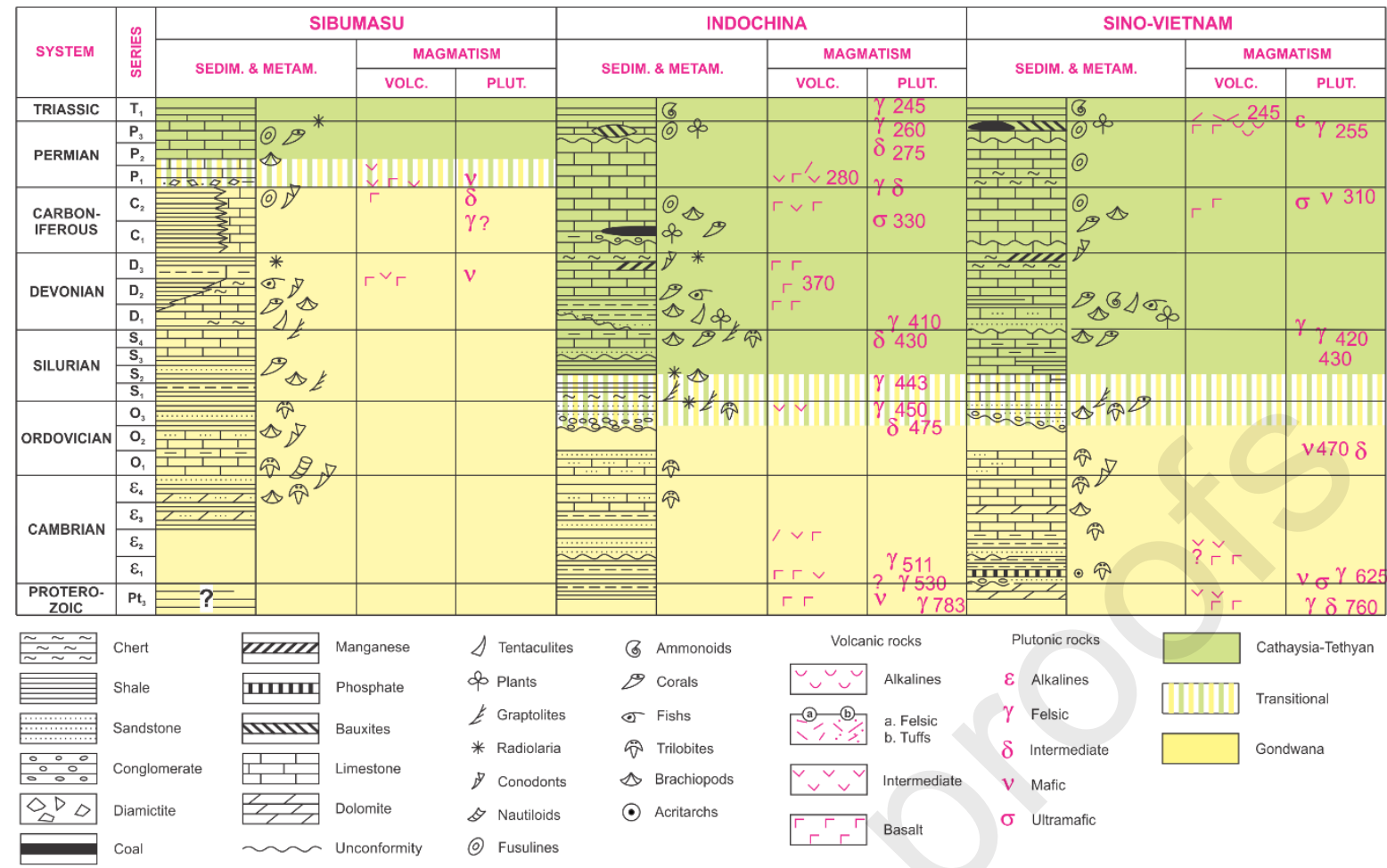

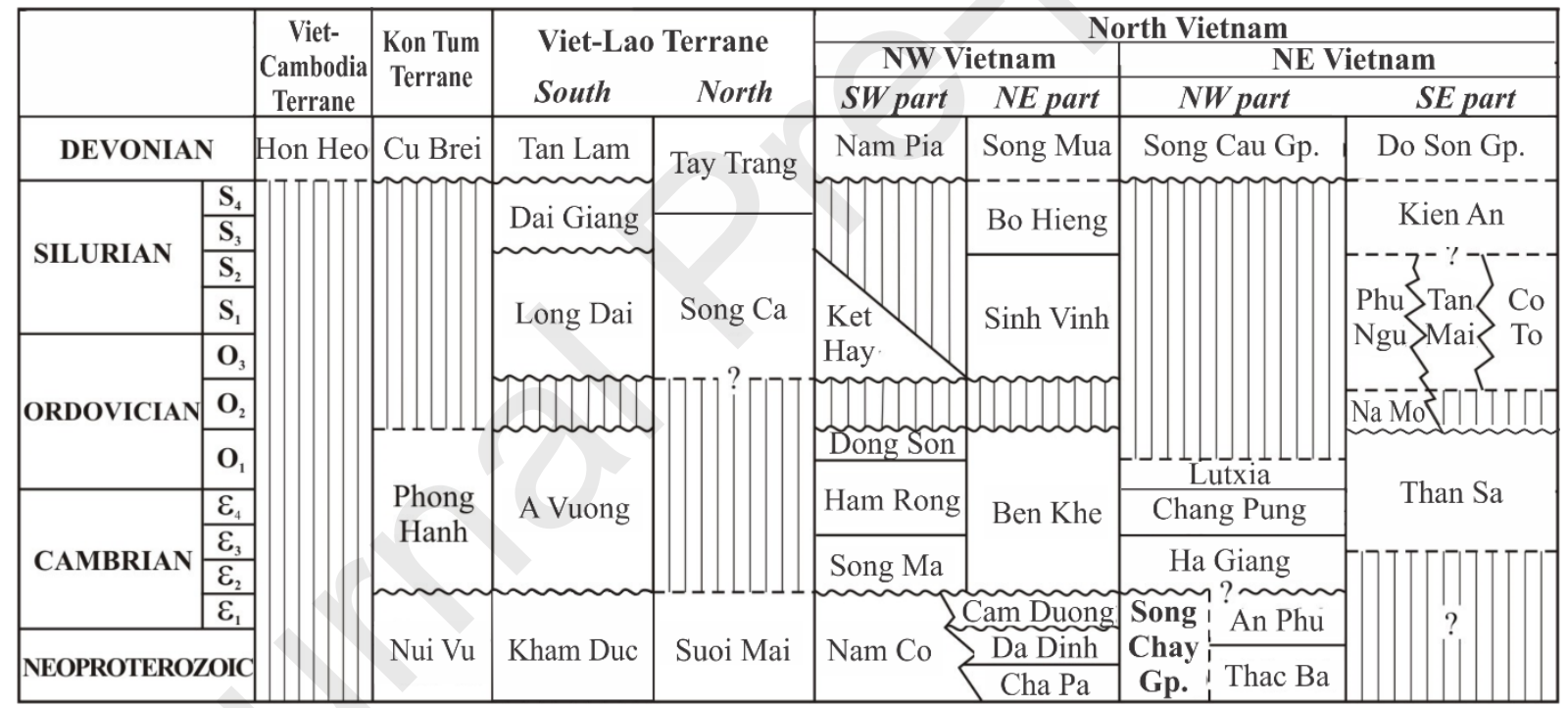
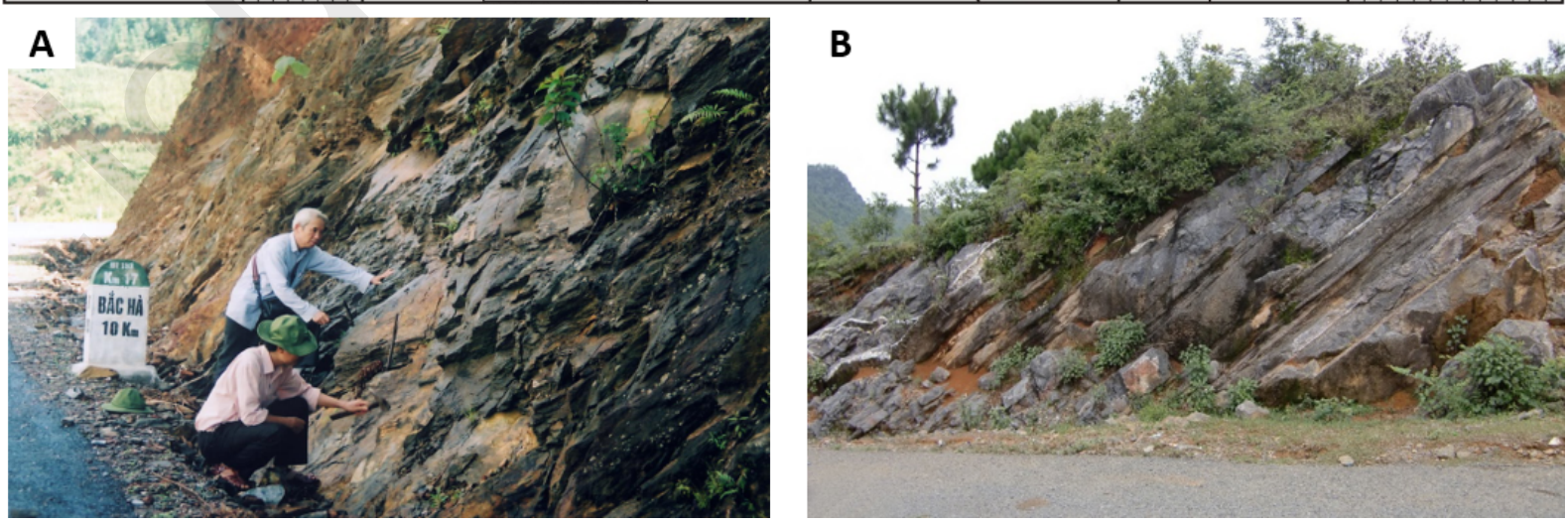


\section{Journal Pre-proofs}
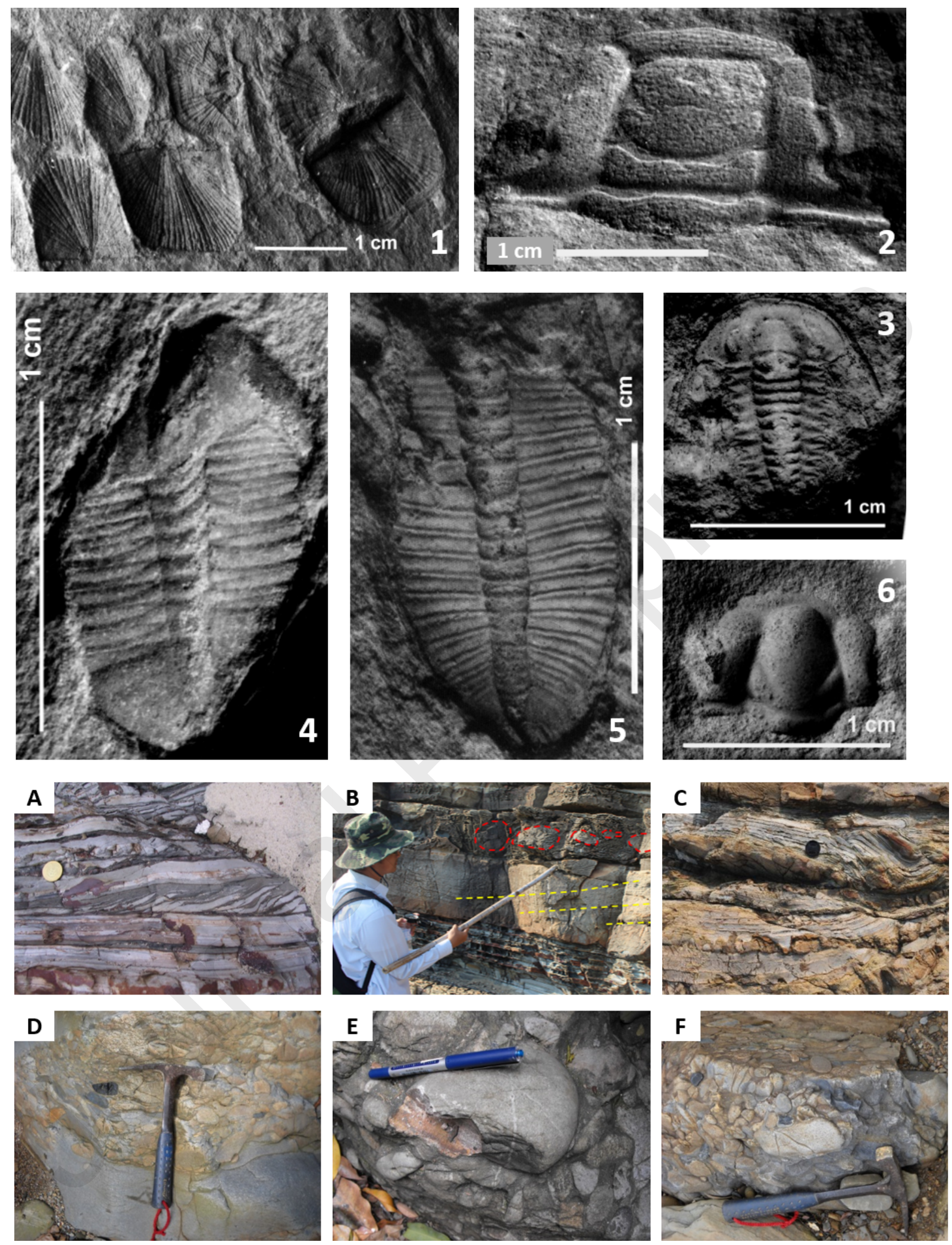

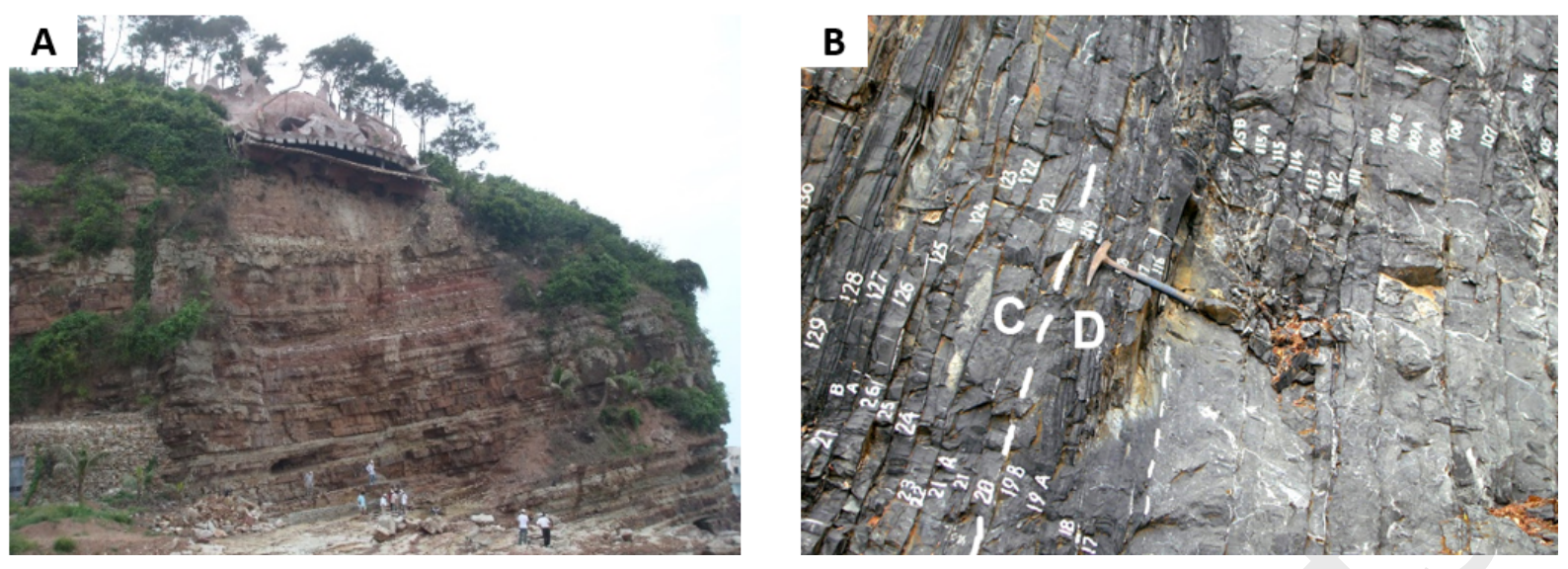


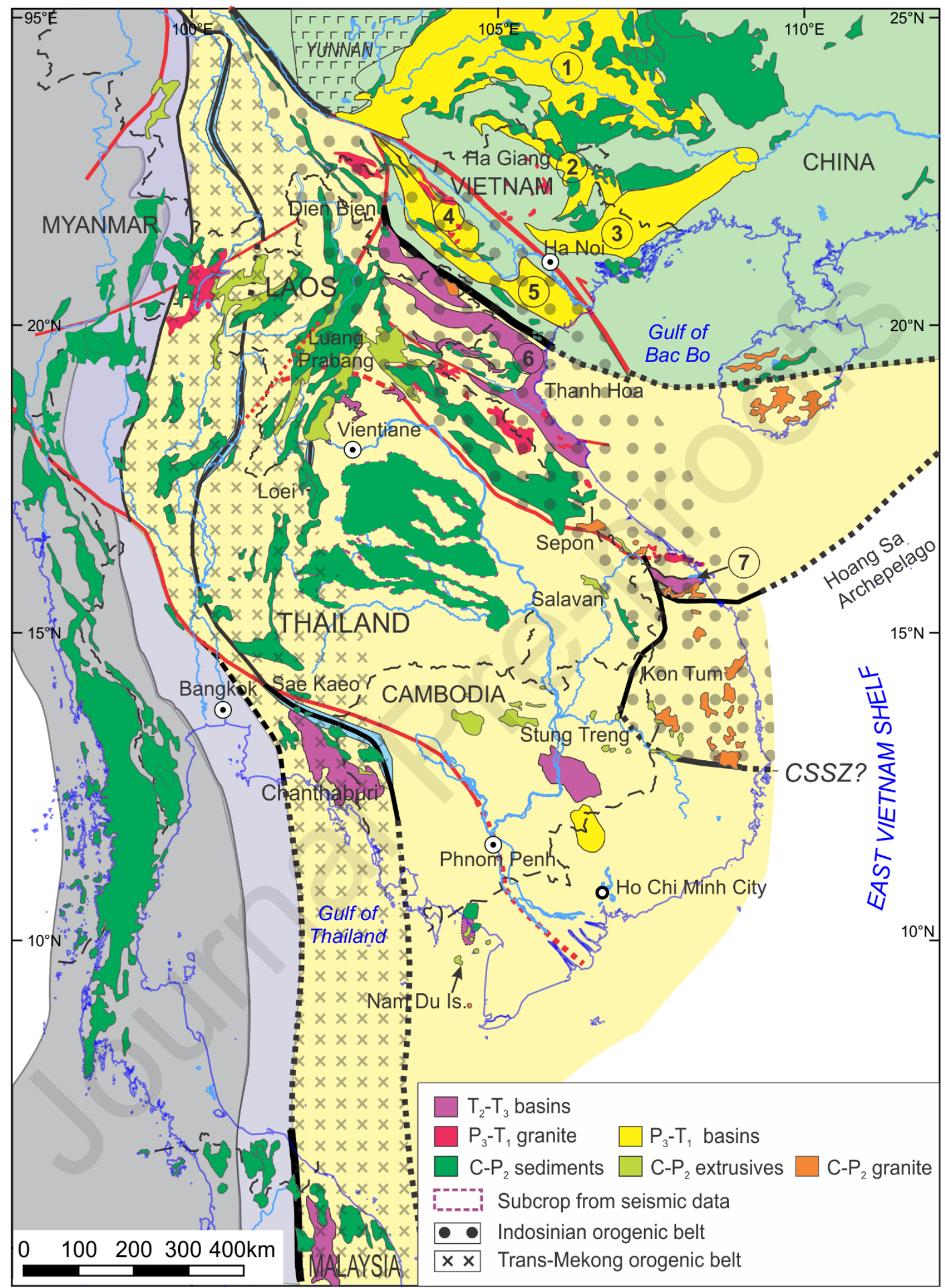


Journal Pre-proofs
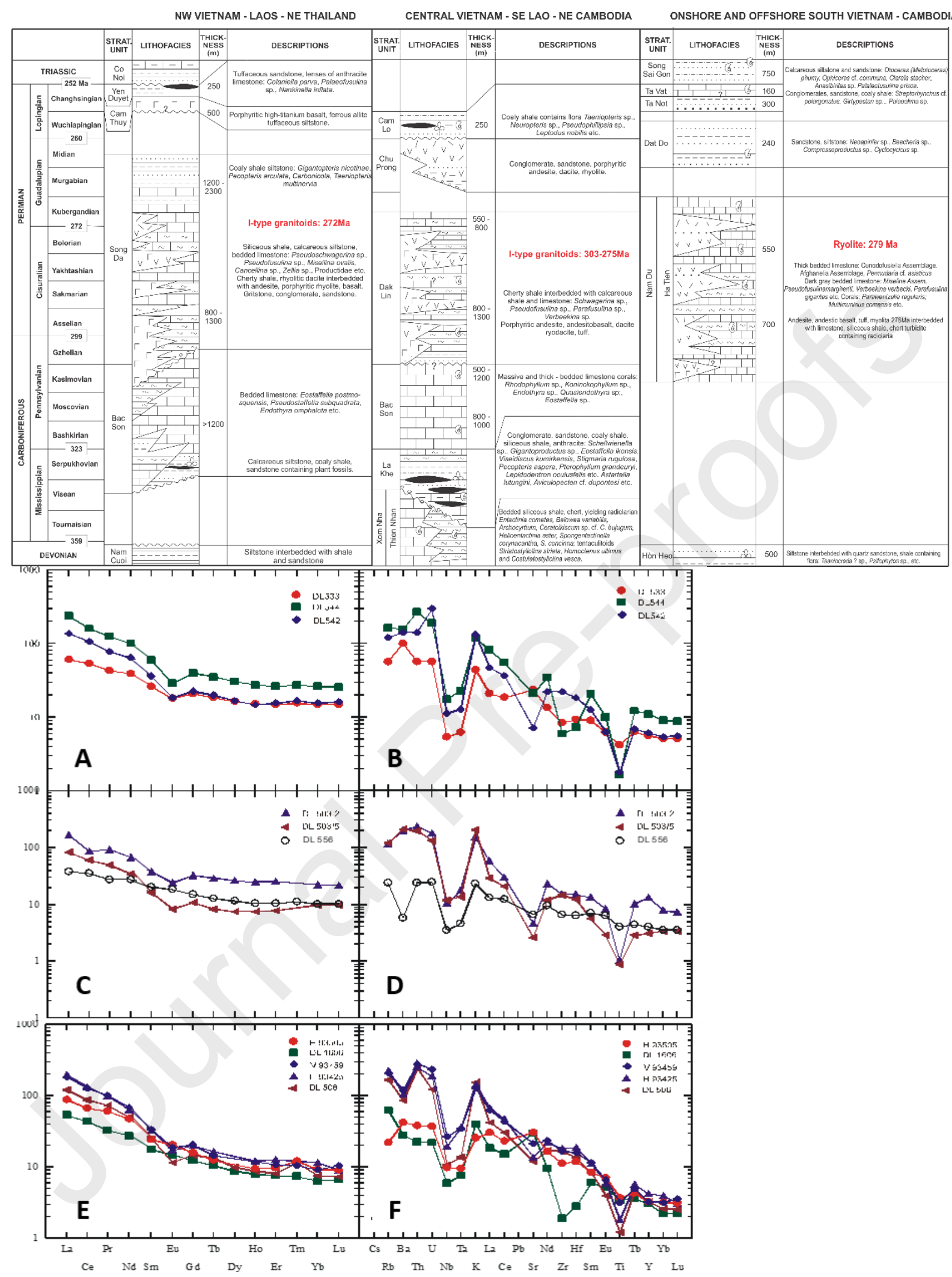

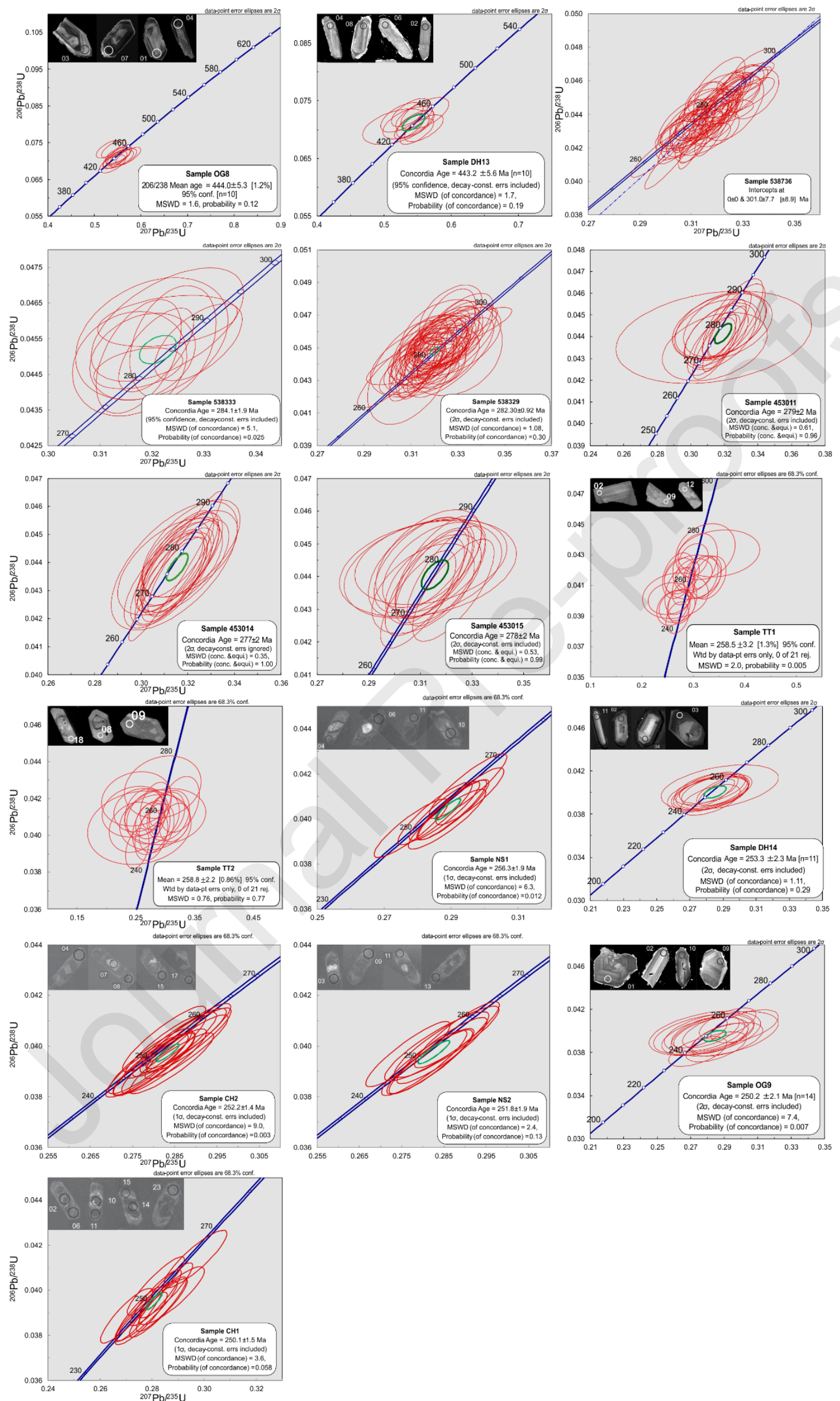


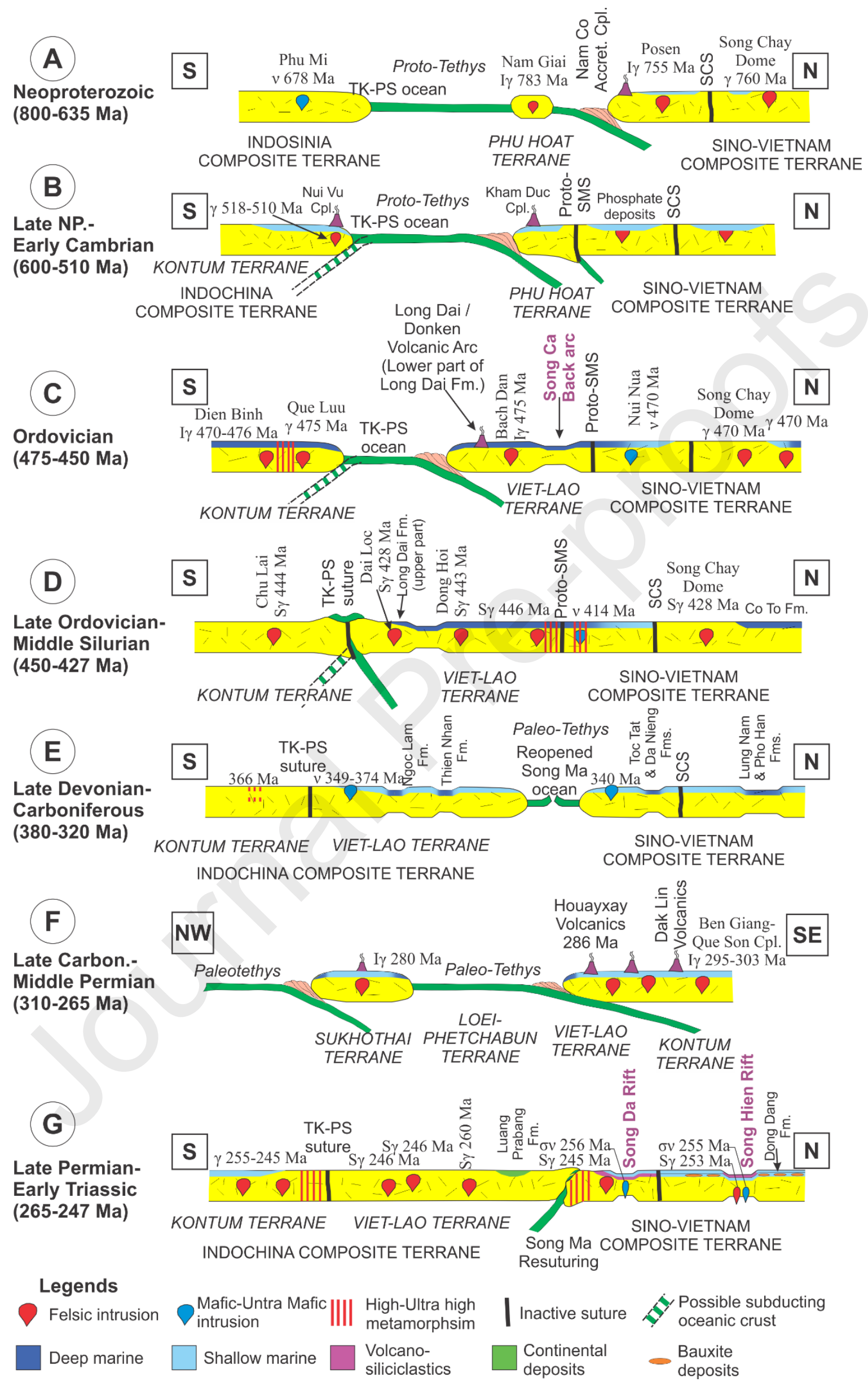


Table 1

\begin{tabular}{|c|c|c|c|c|c|c|c|c|}
\hline $\begin{array}{c}\text { No } \\
\text {. }\end{array}$ & $\begin{array}{l}\text { Sampl } \\
\text { e ID }\end{array}$ & Place & Terrane & Latitude & $\begin{array}{c}\text { Longitu } \\
\text { de }\end{array}$ & Rock type & Age & $\begin{array}{c}\text { Analyze } \\
\text { d by }\end{array}$ \\
\hline 1 & OG08 & $\begin{array}{c}\text { Chu } \\
\text { Lai } \\
\text { quarry }\end{array}$ & $\begin{array}{l}\text { Kon } \\
\text { Tum }\end{array}$ & $\begin{array}{c}15^{\circ} 24^{\prime} \\
27^{\prime \prime}\end{array}$ & $\begin{array}{c}108^{\circ} 40^{\prime} \\
55^{\prime \prime}\end{array}$ & $\begin{array}{l}\text { Granite } \\
\text { migmatite }\end{array}$ & $\begin{array}{c}444.0 \pm 5 \\
.3 \mathrm{Ma}\end{array}$ & $\begin{array}{l}\text { Kyushu } \\
\text { Uni. }\end{array}$ \\
\hline 2 & DH13 & $\begin{array}{l}\text { Dong } \\
\text { Hoi }\end{array}$ & $\begin{array}{l}\text { Viet- } \\
\text { Laos }\end{array}$ & $\begin{array}{c}17^{\circ} 27^{\prime} \\
40^{\prime \prime}\end{array}$ & $\begin{array}{c}106^{\circ} 28^{\prime} \\
02^{\prime \prime}\end{array}$ & $\begin{array}{c}\text { Granodiori } \\
\text { te }\end{array}$ & $\begin{array}{c}443.2 \\
\pm 5.6 \mathrm{Ma}\end{array}$ & $\begin{array}{l}\text { Kyushu } \\
\text { Uni. }\end{array}$ \\
\hline 3 & $\begin{array}{c}53873 \\
6\end{array}$ & $\begin{array}{c}\text { Phno } \\
\text { m } \\
\text { Knarn } \\
\text { g } \\
\text { Takul }\end{array}$ & $\begin{array}{c}\text { Viet- } \\
\text { Cambod } \\
\text { ia }\end{array}$ & $\begin{array}{c}11^{\circ} 01^{\prime} \\
16.2^{\prime \prime}\end{array}$ & $\begin{array}{c}104^{\circ} 24^{\prime} \\
12.2^{\prime \prime}\end{array}$ & Granite & $\begin{array}{c}301.0 \pm 7 \\
.7 \mathrm{Ma}\end{array}$ & GEUS \\
\hline 4 & $\begin{array}{c}53833 \\
3\end{array}$ & $\begin{array}{l}\text { Hon } \\
\text { Doc } \\
\text { Isl. } \\
\text { NE } \\
\end{array}$ & $\begin{array}{c}\text { Viet- } \\
\text { Cambod } \\
\text { ia }\end{array}$ & $\begin{array}{c}10^{\circ} 19^{\prime} \\
15.9^{\prime \prime}\end{array}$ & $\begin{array}{c}104^{\circ} 19^{\prime} \\
57.2^{\prime \prime}\end{array}$ & Rhyolite & $\begin{array}{c}284.1 \\
\pm 1.9 \mathrm{Ma}\end{array}$ & GEUS \\
\hline 5 & $\begin{array}{c}53832 \\
9\end{array}$ & $\begin{array}{l}\text { Hon } \\
\text { Doc } \\
\text { Isl. } \\
\text { SE }\end{array}$ & $\begin{array}{c}\text { Viet- } \\
\text { Cambod } \\
\text { ia }\end{array}$ & $\begin{array}{c}10^{\circ} 19^{\prime} 17 . \\
4^{\prime \prime}\end{array}$ & $\begin{array}{c}104^{\circ} 20^{\prime} \\
13.8^{\prime \prime}\end{array}$ & Felsite & $\begin{array}{c}282.30 \\
\pm 0.92 \\
\mathrm{Ma}\end{array}$ & GEUS \\
\hline 6 & $\begin{array}{c}45301 \\
1\end{array}$ & $\begin{array}{l}\text { Nam } \\
\text { Du } \\
\text { Island }\end{array}$ & $\begin{array}{c}\text { Viet- } \\
\text { Cambod } \\
\text { ia }\end{array}$ & $\begin{array}{l}09^{\circ} 40^{\prime} \\
33.0^{\prime \prime}\end{array}$ & $\begin{array}{c}104^{\circ} 23^{\prime} \\
58.0^{\prime \prime}\end{array}$ & $\begin{array}{c}\text { Rhyodacit } \\
\text { e }\end{array}$ & $\begin{array}{c}279 \pm 2 \\
\mathrm{Ma}\end{array}$ & GEUS \\
\hline 7 & $\begin{array}{c}45301 \\
4\end{array}$ & $\begin{array}{l}\text { Nam } \\
\text { Du } \\
\text { Island }\end{array}$ & $\begin{array}{c}\text { Viet- } \\
\text { Cambod } \\
\text { ia }\end{array}$ & $\begin{array}{c}09^{\circ} 41^{\prime} \\
23^{\prime \prime}\end{array}$ & $\begin{array}{c}104^{\circ} 21^{\prime} \\
05.0^{\prime \prime}\end{array}$ & $\begin{array}{c}\text { Rhyodacit } \\
\text { e }\end{array}$ & $\begin{array}{c}277 \pm 2 \\
\mathrm{Ma}\end{array}$ & GEUS \\
\hline 8 & $\begin{array}{c}45301 \\
5\end{array}$ & $\begin{array}{l}\text { Hon } \\
\text { Mau }\end{array}$ & $\begin{array}{c}\text { Viet- } \\
\text { Cambod } \\
\text { ia }\end{array}$ & $\begin{array}{l}10^{\circ} 01^{\prime} \\
20.0^{\prime \prime}\end{array}$ & $\begin{array}{c}104^{\circ} 32^{\prime} \\
50.0^{\prime \prime}\end{array}$ & Rhyolite & $\begin{array}{c}278 \pm 2 \\
\mathrm{Ma}\end{array}$ & GEUS \\
\hline 9 & TT2 & $\begin{array}{l}\text { Tram } \\
\text { Tau, } \\
\text { Yen } \\
\text { Bai }\end{array}$ & $\begin{array}{c}\text { North } \\
\text { West } \\
\text { Vietnam }\end{array}$ & $\begin{array}{c}21^{\circ} 29 \\
00^{\prime \prime}\end{array}$ & $\begin{array}{c}104^{\circ} 24^{\prime} \\
53^{\prime \prime}\end{array}$ & Rhyolite & $\begin{aligned} & 258.8 \\
\pm & 2.2 \mathrm{Ma}\end{aligned}$ & AIST \\
\hline 10 & TT1 & $\begin{array}{l}\text { Tram } \\
\text { Tau, } \\
\text { Yen } \\
\text { Bai }\end{array}$ & $\begin{array}{c}\text { North } \\
\text { West } \\
\text { Vietnam }\end{array}$ & $\begin{array}{c}21^{\circ} 29 \\
00^{\prime \prime}\end{array}$ & $\begin{array}{c}104^{\circ} 24^{\prime} \\
53^{\prime \prime}\end{array}$ & Rhyolite & $\begin{aligned} & 258.5 \\
\pm & 3.2 \mathrm{Ma}\end{aligned}$ & AIST \\
\hline 11 & NS1 & $\begin{array}{c}\text { Chie } \\
\mathrm{m} \\
\mathrm{Hoa}- \\
\mathrm{Na} \\
\text { Son }\end{array}$ & $\begin{array}{c}\text { North } \\
\text { East } \\
\text { Vietnam }\end{array}$ & $\begin{array}{c}22^{\circ} 55^{\prime} \\
35^{\prime \prime}\end{array}$ & $\begin{array}{c}105^{\circ} 04^{\prime} \\
58^{\prime \prime}\end{array}$ & $\begin{array}{c}\text { quartz } \\
\text { syenite }\end{array}$ & $\begin{array}{c}256.3 \\
\pm 1.9 \mathrm{Ma}\end{array}$ & IESAS \\
\hline 12 & DH14 & $\begin{array}{c}\text { Dong } \\
\text { Hoi }\end{array}$ & $\begin{array}{l}\text { Viet- } \\
\text { Laos }\end{array}$ & $\begin{array}{c}17^{\circ} 23^{\prime} \\
27^{\prime \prime}\end{array}$ & $\begin{array}{c}106^{\circ} 28^{\prime} \\
49^{\prime \prime}\end{array}$ & Granite & $\begin{array}{r}253.3 \\
\pm 2.3 \mathrm{Ma} \\
\end{array}$ & $\begin{array}{c}\text { Kyushu } \\
\text { Uni. }\end{array}$ \\
\hline 13 & $\mathrm{CH} 2$ & $\begin{array}{c}\text { Chie } \\
\text { m } \\
\text { Hoa- }\end{array}$ & $\begin{array}{c}\text { North } \\
\text { East } \\
\text { Vietnam }\end{array}$ & $\begin{array}{c}22^{\circ} 10^{\prime} \\
27^{\prime \prime}\end{array}$ & $\begin{array}{c}105^{\circ} 18^{\prime} \\
49^{\prime \prime}\end{array}$ & Granite & $\begin{array}{c}252.2 \\
\pm 1.4 \mathrm{Ma}\end{array}$ & IESAS \\
\hline
\end{tabular}




\begin{tabular}{|c|c|c|c|c|c|c|c|c|}
\hline & & $\begin{array}{l}\mathrm{Na} \\
\text { Son }\end{array}$ & & & & & & \\
\hline 14 & NS2 & $\begin{array}{c}\text { Chie } \\
\mathrm{m} \\
\mathrm{Hoa}- \\
\mathrm{Na} \\
\text { Son }\end{array}$ & $\begin{array}{c}\text { North } \\
\text { East } \\
\text { Vietnam }\end{array}$ & $\begin{array}{c}22^{\circ} 55^{\prime} \\
17^{\prime \prime}\end{array}$ & $\begin{array}{c}105^{\circ} 05^{\prime} \\
13^{\prime \prime}\end{array}$ & $\begin{array}{l}\text { quartz } \\
\text { syenite }\end{array}$ & $\begin{array}{c}251.8 \\
\pm 1.9 \mathrm{Ma}\end{array}$ & IESAS \\
\hline 15 & OG09 & $\begin{array}{l}\text { Cha } \\
\text { Val }\end{array}$ & $\begin{array}{l}\text { Kon } \\
\text { Tum }\end{array}$ & $\begin{array}{c}15^{\circ} 38^{\prime} \\
23^{\prime \prime}\end{array}$ & $\begin{array}{c}107^{\circ} 32^{\prime} \\
43^{\prime \prime}\end{array}$ & Gabbro & $\begin{array}{c}250.2 \\
\pm 2.1 \mathrm{Ma}\end{array}$ & $\begin{array}{c}\text { Kyushu } \\
\text { Uni. }\end{array}$ \\
\hline 16 & CH1 & $\begin{array}{c}\text { Chie } \\
\mathrm{m} \\
\mathrm{Hoa}- \\
\mathrm{Na} \\
\text { Son }\end{array}$ & $\begin{array}{c}\text { North } \\
\text { East } \\
\text { Vietnam }\end{array}$ & $\begin{array}{c}22^{\circ} 10^{\prime} \\
27^{\prime \prime}\end{array}$ & $\begin{array}{c}105^{\circ} 18^{\prime} \\
49^{\prime \prime}\end{array}$ & Granite & $\begin{array}{c}250.1 \\
\pm 1.5 \mathrm{Ma}\end{array}$ & IESAS \\
\hline
\end{tabular}


- Tri Tran Van: Conceptualization, Methodology, Formal analysis, Investigation, Resources, Writing - Original Draft, Writing - Review \& Editing, Supervision, Project administration

- Michel Faure: Methodology, Validation, Verification, Formal analysis, Investigation, Resources, Writing - Review \& Editing

- Vuong Van Nguyen: Methodology, Formal analysis, Investigation, Resources, Writing Original Draft, Writing - Review \& Editing

- Hoang Huy Bui: Investigation, Writing - Original Draft, Writing - Review \& Editing, Visualization

- Michael Bryld Wessel Fyhn: Investigation, Resources, Writing - Review \& Editing

- Tuan Quang Nguyen: Investigation, Visualization

- Claude Lepvrier: Writing - Review \& Editing

- Tonny B. Thomsen: Formal analysis, Resources

- Kenichiro Tani: Formal analysis, Resources

- Punya Charusiri: Writing - Review \& Editing 


\section{Declaration of interests}

We, the undersigned, declare that we have no known competing financial interests or personal relationships that could have appeared to influence the work reported in this paper.

Tran Van Tri 